\title{
INDIRANA CHIRAVASI, A NEW SPECIES OF LEAPING FROG (ANURA: RANIXALIDAE) FROM WESTERN GHATS OF INDIA
}

\author{
Anand D. Padhye ${ }^{1}$, Nikhil Modak ${ }^{2}$ \& Neelesh Dahanukar ${ }^{3}$ \\ ${ }^{1}$ Department of Zoology, Abasaheb Garware College, Karve Road, Pune, Maharashtra 411004, India \\ ${ }^{2}$ Department of Biodiversity, Abasaheb Garware College, Karve Road, Pune, Maharashtra 411004, India \\ ${ }^{3}$ Indian Institute of Science Education and Research (IISER), G1 Block, Dr. Homi Bhabha Road, Pashan, Pune, \\ Maharashtra 411008, India \\ ${ }^{3}$ Systematics, Ecology and Conservation Laboratory, Zoo Outreach Organization (ZOO), 96 Kumudham Nagar, \\ Vilankurichi Road, Coimbatore, Tamil Nadu 641035, India \\ ${ }^{1}$ anand.padhye@mesagc.org (corresponding author), ${ }^{2}$ nikhilsmodak@gmail.com, ${ }^{3}$ n.dahanukar@iiserpune.ac.in
}

ISSN

Online 0974-7907

Print 0974-7893

Abstract: Indirana chiravasi, a new species of leaping frog is described from the northern Western Ghats around Amboli, Sindhudurg District, Maharashtra, India. It differs from all its congeners based on a combination of characters including presence of median single internal vocal sac, head longer than wide, distinct canthus rostralis, tympanum $2 / 3^{\text {rd }}$ to $3 / 4^{\text {th }}$ the diameter of eye, vomerine teeth in two oblique series at the posterior border of choanae, long midventral lingual papilla, first finger longer than or equal to second, presence of double outer palmer tubercle, thin and elongated inner metatarsal tubercle, absence of outer metatarsal tubercle, webbing moderate, dorsal skin with glandular folds but without warts, ventral skin smooth without mottling and palms and soles dark brown. Molecular analysis based on mitochondrial $12 \mathrm{~S}$ and $16 \mathrm{~S}$ genes and nuclear rhodopsin and rag1 genes suggests that the species is genetically distinct from other species for which genetic data is available. Preliminary observations on the development of the species are also provided. We also provide genetic data and images for Indirana gundia collected from the type locality.

Keywords: Endemic frogs, Indirana gundia, molecular phylogeny, new species, taxonomy.
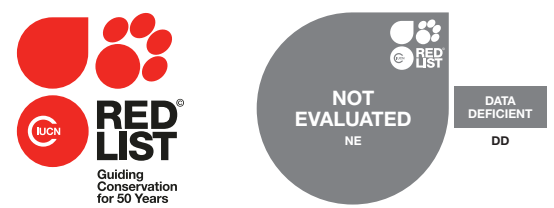

Indirana chiravasi Amboli Leaping Frog
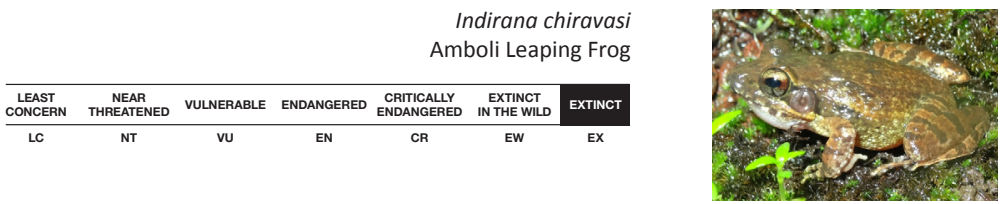

DOI: http://dx.doi.org/10.11609/JoTT.o4068.6293-312 | ZooBank: urn:Isid:zoobank.org:pub:89196447-08BF-4F56-B37F-78A617DCCFB2

Editor: Annemarie Ohler, Muséum national d'Histoire naturelle, Paris, France.

Date of publication: 26 September 2014 (online \& print)

Manuscript details: Ms \# 04068 | Received 23 June 2014 | Final received 16 September 2014 | Finally accepted 17 September 2014

Citation: Padhye, A.D., N. Modak \& N. Dahanukar (2014). Indirana chiravasi, a new species of Leaping Frog (Anura: Ranixalidae) from Western Ghats of India. Journal of Threatened Taxa 6(10): 6293-6312; http://dx.doi.org/10.11609/JoTT.04068.6293-312

Copyright: (C) Padhye et al. 2014. Creative Commons Attribution 4.0 International License. JoTT allows unrestricted use of this article in any medium, reproduction and distribution by providing adequate credit to the authors and the source of publication.

Funding: Nikhil Modak is supported by DST-INSPIRE Student Fellowship [IF 120398]. Nikhil Modak was supported by Ernst Mayr Travel Grant, MCZ, Harvard University, US, for examination of specimens at BMNH, London and MNHN, Paris. Neelesh Dahanukar is supported by DST-INSPIRE Faculty Fellowship and Research Grant [IFA12- LSBM-21].

Conflict of Interest: The authors declare no competing interests. Funding sources had no role in study design, data collection, results interpretation and manuscript writing.

For Author Details and Author Contribution see end of this article.

Acknowledgements: We thank Head of the Zoology and Biodiversity Departments and Principal, MES Abasaheb Garware College, Pune and Indian Institute of Science Education and Research, Pune, for providing infrastructural facilities. We are thankful to Dr. H.V. Ghate for helpful discussions and valuable suggestions. We are grateful to Dr. Asad Rahmani, Director; Dr. Deepak Apte, COO; Rahul Khot, incharge Natural History Collection; and Vithoba Hegde, senior field assistant, for their help during study of the museum specimens and registration of specimens at Bombay Natural History Society (BNHS), Mumbai. NM wishes to specially thank Dr. Barry Clarke, Curator; Dr. David Gower and Dr. Ralph Britz for their help and advice while working at Natural History Museum (BMNH), London. NM is indebted to Dr. Annemarie Ohler of Amphibians and Reptiles section, Muséum national d'Histoire naturelle (MNHN) for her help and guiding discussions about taxonomy. NM is also thankful to the staff at BMNH and MNHN for their kind help. We also thank Dr. P.S. Bhatnagar, officer-in-charge, and Dr. Shrikant Jadhav, Zoological Survey of India, Western Regional Center (ZSI-WRC), Pune, for their help in registering specimens in ZSI-WRC. We are thankful to Dr. Sanjay Molur and Keerthi Krutha for helping in registration of specimens in the Wildlife Information Liaison Development (WILD), Coimbatore. We thank Avishkar Munje, Shauri Sulakhe, Abhijeet Bayani and Unmesh Katwate for photographying the material. NM would like to thank Hemant Ogle for providing stay and help during field work at Amboli. We would also like to thank Abhijeet Bayani, Anushree Jadhav, Anil Pujari, Chandrakant Redican, Keerti Krutha, Sameer Padhye, Sayali Sheth, Shauri Sulakhe, Shriraj Jakhalekar, Shruti Paripatyadar, Siddharth Kulkarni, and Unmesh Katwate for assisting in field work. 


\section{INTRODUCTION}

The genus Indirana Laurent, 1986, is one of the 10 endemic anuran genera of the Western Ghats of India and the sole member of the family Ranixalidae Dubois, 1987. Genus Indirana, which has terrestrial tadpoles, is characterized by the presence of vomerine teeth, midventral lingual papilla, keratodont formula of 3-5/3-4, $\mathrm{T}$ or Y-shaped terminal phalanges and absence of terminal intercalary cartilage (Laurent 1986; Frost et al. 2006). Currently, genus Indirana comprises of 10 valid species, namely Indirana beddomii (Günther, 1876), I. brachytarsus (Günther, 1876), I. diplosticta (Günther, 1876), I. leptodactyla (Boulenger, 1882), I. phrynoderma (Boulenger, 1882), I. semipalmata (Boulenger, 1882), I. leithii (Boulenger, 1888), I. longicrus (Rao, 1937), I. tenuilingua (Rao, 1937) and I. gundia (Dubois, 1986).

The true species diversity of Indirana within the Western Ghats, however, is poorly understood as several species are suggested to be in species complexes (Nair et al. 2012a,b; Modak et al. 2014). With the presence of undescribed species (Nair et al. 2012a,b; Modak et al. 2014) and poor knowledge on the distribution of known species (Modak et al. 2014), the knowledge on Indirana is plagued by both Linnean and Wallacean shortfalls (Bini et al. 2006). Because several species of Indirana are under threatened category (Stuart et al. 2008), taxonomic studies on this group are of immediate concern.

While studying the diversity and distribution of species under the genus Indirana, we came across a population showing marked difference in morphology from its congeners and genetically distinct from species for which genetic data is available. This population is described as a new species of Indirana from Amboli, in Western Ghats of southern Maharashtra, India.

\section{MATERIALS AND METHODS}

\section{Study site and specimen collection}

Specimens of the new species were collected from Amboli $\left(15.956^{\circ} \mathrm{N}\right.$ \& $\left.73.997^{\circ} \mathrm{E} ; 744 \mathrm{~m}\right)$, Sindhudurg District, Maharashtra, India. Five male and two female specimens were collected and preserved in absolute alcohol for further analysis. Two specimen of Indirana gundia were collected from non-protected area of Gundia, Karnataka, for genetic analysis. Collection of specimens was kept at the minimum and all collections were made following the IUCN (2008) guidelines for use of threatened species in research.

\section{Museum details}

Specimens studied in this paper are deposited in the museum collection of Natural History Museum, London (BMNH); Muséum National de histoire Naturelle, Paris (MNHN), Bombay Natural History Society, Mumbai (BNHS); Wildlife information Liaison Development Society, Coimbatore (WILD) and Zoological Survey of India, Western Regional Center, Pune (ZSI-WRC). Inger et al. (1984) designated BMNH 1947.2.27.92 as a lectotype of Indirana brachytarsus. Therefore, we have considered the specimen BMNH 1947.2.2.85, currently a syntype of $I$. brachytarsus, as paralectotype.

\section{Morphometry}

Morphometry was done with the help of a digital caliper (Ocean Premium measuring instruments) to the nearest $0.1 \mathrm{~mm}$. Totally, 27 characters were selected following Biju et al. (2011) and Dubois \& Ohler (1999) with some modifications for morphometry, viz.-SUL (Length of specimen from snout to the visible tip of urostyle); HL (head length: from the posterior border of tympanum to the tip of snout); HW (head width: width of head between to posterior borders of tympanum); SL (Snout Length: from the anterior orbital border to the tip of snout); EL (Eye Length: length of eye between two orbital borders); TYL (maximum tympanum length); UEW (upper eyelid width); SNL (snout to nostril distance); ENL (eye to nostril distance); INL (inter-narial distance); IOL (inter-orbital distance: minimum distance between two eyelids); UAL (Upper arm length); FoAL (Fore-arm Length); F1 to F4 (Finger 1 to Finger 4 length from the base of the sub-articular tubercle); F3D (finger three disc width); F3W (finger three width at the base of disc); THL (thigh length); TL (Tibia/shank length); ACL (Astragalocalcaneal length); FOL (Foot length: from the base of the inner metatarsal tubercle to the tip of the fourth toe); TFOL (Total foot length: from the tibio-tarsal articulation to the tip of fourth toe) and T1 to T5 (Toe1 to Toe5 length from the base of the respective sub-articular tubercle). Webbing formula was determined following the method provided by Savage \& Heyer (1967) with modifications by Myers \& Duellman (1982).

\section{Statistical analysis}

Statistical analysis of the morphometric data was performed on size adjusted measurements by taking all measurements as percent of SUL. The null hypothesis that the data is multivariate normal was checked using Doornik \& Hansen (2008) omnibus. MANOVA/CVA was performed to understand whether related species of Indirana form significantly different clusters (Huberty 
Table 1. Primers used for molecular study along with melting temperature ( $\mathrm{Tm}$ ) and annealing temperatures (Ta).

\begin{tabular}{|c|c|c|c|c|}
\hline Primer & Sequence $\left(5^{\prime} \rightarrow 3^{\prime}\right)$ & $\operatorname{Tm}\left({ }^{\circ} \mathrm{C}\right)$ & $\mathrm{Ta}\left({ }^{\circ} \mathrm{C}\right)$ & Reference \\
\hline $12 \mathrm{SF}$ & AAACTGGGATTAGATACCCCACTAT & 55.1 & \multirow{2}{*}{56} & \multirow{2}{*}{ Simon et al. (1994) } \\
\hline $12 S R$ & GAGGGTGACGGGCGGTGTGT & 64.8 & & \\
\hline $16 S F$ & CGCCTGTTTATCAAAAACAT & 49.2 & \multirow{2}{*}{50} & \multirow{2}{*}{ Palumbi et al. (1991) } \\
\hline $16 S R$ & CCGGTCTGAACTCAGATCACGT & 58.6 & & \\
\hline RhoF & ACCATGAACGGAACAGAAGGYCC & 60.4 & \multirow{2}{*}{56} & \multirow{2}{*}{ Bossuyt \& Milinkovitch (2000) } \\
\hline RhoR & GTAGCGAAGAARCCTTCAAMGTA & 54.9 & & \\
\hline Rag1F & ATGGGAGATGTGAGTGARAARCA & 56.2 & \multirow{2}{*}{54} & \multirow{2}{*}{ Biju \& Bossuyt 2003} \\
\hline Rag1R & TCCGCTGCATTTCCRATGTCRCA & 60.2 & & \\
\hline
\end{tabular}

\& Olejnik 2006). Pillai's trace statistic was performed to find the significant difference between the clusters (Harris 2001). Statistical analysis was performed in PAST (Hammer et al. 2001).

\section{Molecular analysis}

Two specimens of the new species (BNHS 5890 and WILD-14-AMP-489) and two specimens of topotypic Indirana gundia (WILD-14-AMP-499 and WILD-14AMP-500) were used for molecular work. Genomic DNA was extracted from thigh muscle tissue. The tissue was digested at $55^{\circ} \mathrm{C}$ using STE buffer (50 mM Tris- $\mathrm{HCl}, 20$ mM EDTA and $50 \mu \mathrm{l}$ of $10 \%$ SDS) with $10 \mu \mathrm{l}$ of $20 \mathrm{mg} /$ $\mathrm{ml}$ Proteinase $\mathrm{K}$. RNase treatment was given for two hours at $37^{\circ} \mathrm{C}$. Final extraction process was done using phenol-chloroform method. Polymerase Chain Reaction was performed for amplification of two mitochondrial genes (12S and 16S) and two nuclear genes (rho and rag 1 ) (Table 1 ). In addition to the DNA extracted in the current study, we also used DNA extracted in a previous study (Modak et al. 2014) for amplification of Rag1 gene from two topotypes of Indirana leithii BNHS 5590 and BNHS 5591. PCR reaction was performed in a $25 \mu$ l reaction volume containing $5 \mu$ of template DNA ( 200ng), $2.5 \mu \mathrm{l}$ of $10 \mathrm{X}$ reaction buffer (100 mM Tris $\mathrm{pH}$ 9.0, $500 \mathrm{mM} \mathrm{KCl}, 15 \mathrm{mM} \mathrm{MgCl} 2,0.1 \%$ Gelatin), $2 \mu \mathrm{l}$ of $25 \mathrm{mM} \mathrm{MgCl} 2,1 \mu \mathrm{l}$ of $10 \mathrm{mM}$ dNTPs, $1 \mu \mathrm{l}$ of each primer, $1 \mu \mathrm{l}$ Taq polymerase and $16.5 \mu \mathrm{l}$ nuclease free water. The thermal profile was 10 minutes at $95^{\circ} \mathrm{C}$, and 35 cycles of 1 minute at $94^{\circ} \mathrm{C}, 1$ minute at respective annealing temperature for $12 \mathrm{~S}, 16 \mathrm{~S}$, rho and rag1 primers (Table 1) and 2 minutes at $72^{\circ} \mathrm{C}$, followed by extension of 10 minutes at $72^{\circ} \mathrm{C}$. Amplified DNA fragments were purified using the 'Promega Wizard Gel and PCR clean up' system and sequenced. The purified PCR products were sequenced using $A B I$ prism 3730 sequencer (Applied Biosystems, USA) and Big dye terminator sequencing kit (ABI Prism, USA). Sequences were analyzed by BLAST tool (Altschul et al. 1990). These sequences have been deposited in GenBank (Accession numbers KM386526KM386543).

Additional sequences of related species were retrieved from NCBI GenBank database (http://www. ncbi.nlm.nih.gov/). GenBank accession numbers for the sequences used for the analysis are provided in Appendix A. Gene sequences were aligned separately using MUSCLE (Edgar 2004) implemented in MEGA 6 (Tamura et al. 2013) and were concatenated to make a combined matrix of 1342 nucleotides. Best fit model for nucleotide substitution was selected in TOPALi v2.5 (Milne et al. 2004) based on minimum Akaike Information Criterion (AIC) value (Posada \& Crandall 2001). The phylogenetic relationships were inferred by maximum likelihood analysis using RAxML (Stamatakis 2006) implemented in TOPALi v2.5 (Milne et al. 2004). Reliability of the phylogenetic tree was estimated using bootstrap values run for 1000 iterations.

\section{RESULTS}

\section{Indirana chiravasi sp. nov.}

(Images 1, 2, 3a-c, 4a-b, 5, 6, 8, 9, 10)

urn:Isid:zoobank.org:act:21DA778F-2F2A-4FD8-9551-85D734A5BB45

\section{Holotype}

BNHS 5888, male, 11.vi.2013, 27.3mm SUL, Amboli, Sindhudurg District, Maharashtra, India, coll. Nikhil Modak, Neelesh Dahanukar, Keerthi Krutha and Unmesh Katwate.

\section{Paratypes}

BNHS 5889, female, 9.vi.2014, 39.2mm SUL, Amboli, Sindhudurg District, Maharashtra, India, coll. Nikhil Modak; BNHS 5890, male, 11.vi.2013, 25.0mm SUL, Amboli, Sindhudurg District, Maharashtra, India, coll. 


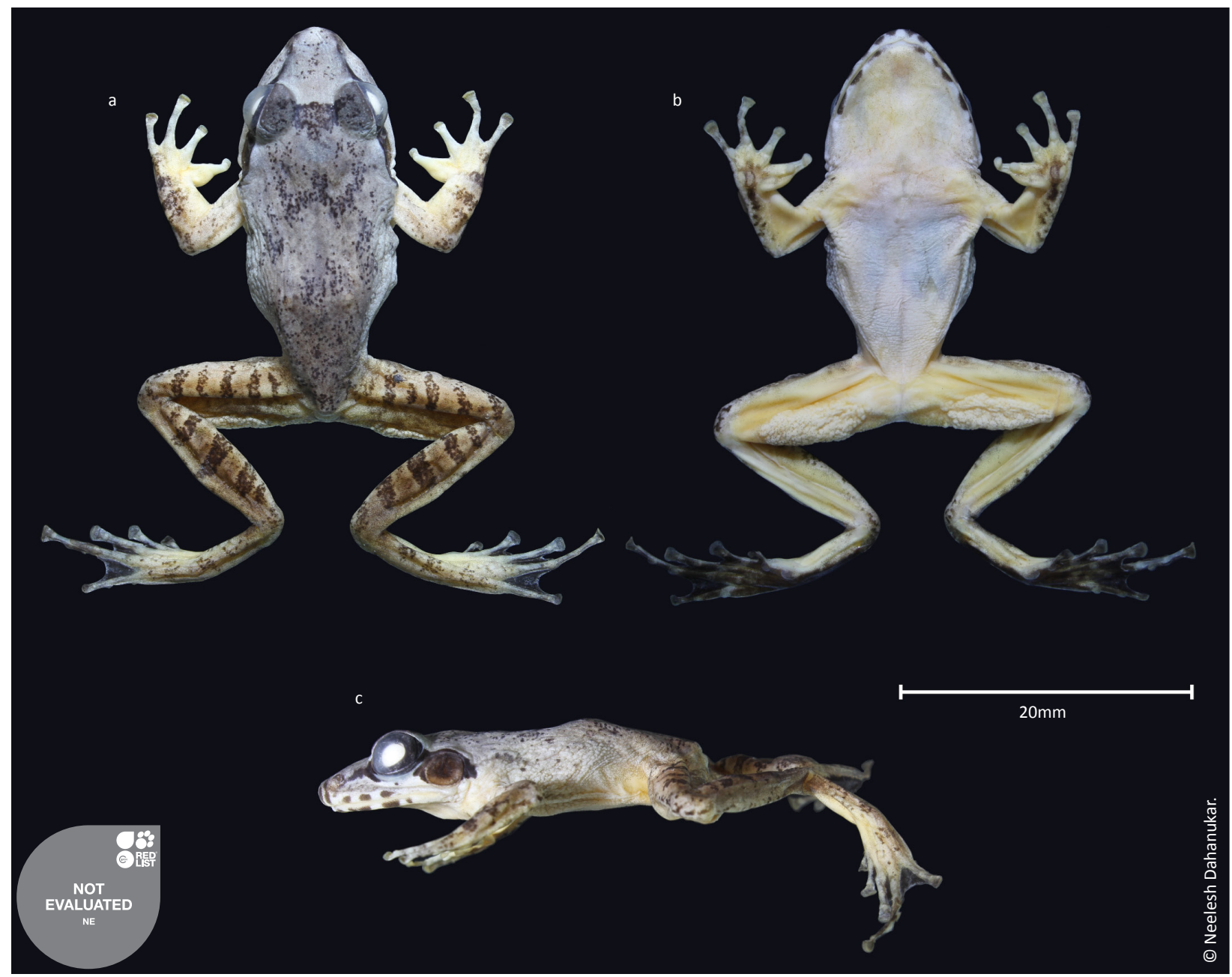

Image 1. Holotype (male) of Indirana chiravasi sp. nov. (BNHS 5888).

Nikhil Modak, Neelesh Dahanukar, Keerthi Krutha and Unmesh Katwate; WILD-14-AMP-489, male, 11.vi.2013, 24.7mm SUL, Amboli, Sindhudurg District, Maharashtra, India, coll. Nikhil Modak, Neelesh Dahanukar, Keerthi Krutha and Unmesh Katwate; WILD-14-AMP-490, $31.7 \mathrm{~mm}$ SUL, female, 9.vi.2014, Amboli, Sindhudurg District, Maharashtra, India, coll. Nikhil Modak; WILD14-AMP-491, male, 19.vi.2013, 25.6mm SUL, Amboli, Sindhudurg District, Maharashtra, India, coll. Nikhil Modak, Neelesh Dahanukar, Keerthi Krutha and Unmesh Katwate; ZSI-WRC A/1541, male, 11.vi.2013, 25.2mm SUL, Amboli, Sindhudurg District, Maharashtra, India, coll. Nikhil Modak, Neelesh Dahanukar, Keerthi Krutha and Unmesh Katwate.

\section{Diagnosis}

Indirana chiravasi sp. nov. differs from all other congeners based on the following combination of characters: medium-sized (24.7-39.2 mm SUL) frog, with median single internal vocal sac, head longer than wide, distinct canthus rostralis, tympanum $3 / 4^{\text {th }}$ the diameter of eye in males and $2 / 3^{\text {rd }}$ in females, vomerine teeth in two oblique series at the posterior border of choanae, long midventral lingual papilla, first finger longer than or equal to second, presence of double outer palmer tubercle, thin and elongated inner metatarsal tubercle present, outer metatarsal tubercle absent, webbing moderate and differs in male (I1-2II1-3III11/4-3IV3$\left.1 \frac{1}{4} \mathrm{~V}\right)$ and female $\left(|1-2|\left|1-2 \frac{1}{2}\right||| 1 \frac{1}{4}-3 \mid \mathrm{V} 3-1 \frac{1}{4} \mathrm{~V}\right)$ by having reduced webbing on the third toe in males as compared to females, dorsally skin with glandular folds but without warts, ventrally skin smooth without mottling and palms and soles dark brown.

\section{Description}

General appearance of holotype as in Image 1 and of female paratype as in Image 2. Morphometric details as in Table 2. 


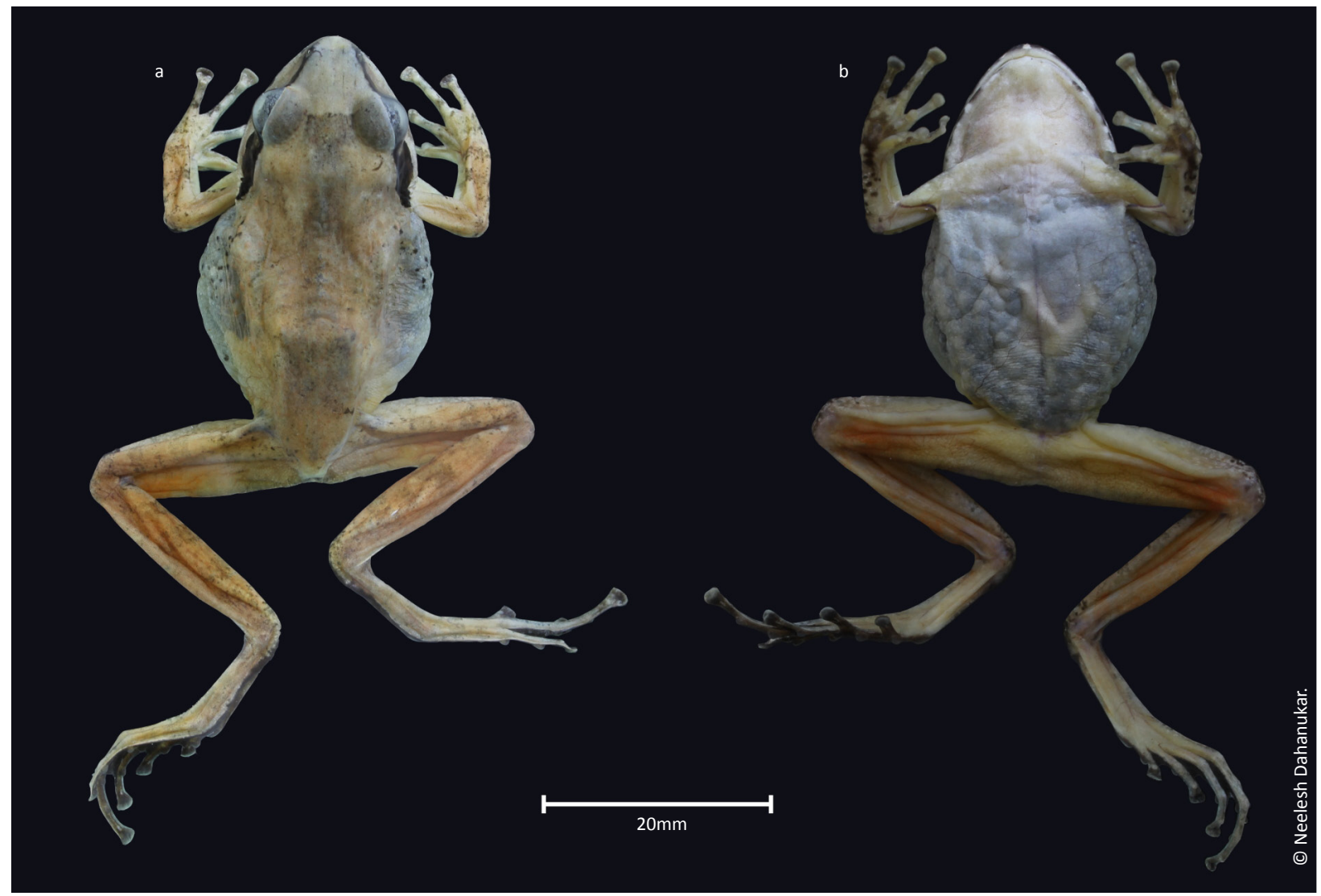

Image 2. Female paratype of Indirana chiravasi sp. nov. (BNHS 5889).

Table 2. Morphometric data ( $\mathrm{mm}$ ) of Indirana chiravasi sp. nov.

\begin{tabular}{|l|l|l|l|l|l|l|l|l|l|l|l|l|l|l|l|l|}
\hline Voucher number & Type status & Gender & SUL & HL & HW & SL & EL & TYL & UEW & SNL & ENL & INL & IOL & UAL & FoAL & F1 \\
\hline BNHS 5888 & Holotype & Male & 27.3 & 11.4 & 9.8 & 4.8 & 3.7 & 2.8 & 2.0 & 2.0 & 2.7 & 2.6 & 2.6 & 5.3 & 6.0 & 2.4 \\
\hline WILD-14-AMP-489* & Paratype & Male & 24.7 & 10.5 & 8.9 & 4.8 & 3.3 & 2.5 & 2.1 & 1.6 & 2.9 & 2.5 & 3.1 & 3.7 & 5.7 & 1.9 \\
\hline BNHS 5890* & Paratype & Male & 25.0 & 10.8 & 9.0 & 4.7 & 3.1 & 2.3 & 1.8 & 1.7 & 2.7 & 2.0 & 2.9 & 3.3 & 5.4 & 1.9 \\
\hline ZSI-WRC A/1541 & Paratype & Male & 25.2 & 11.0 & 9.2 & 4.8 & 3.2 & 2.4 & 2.1 & 1.9 & 2.9 & 2.4 & 2.5 & 4.7 & 5.5 & 2.0 \\
\hline WILD-14-AMP-491 & Paratype & Male & 25.6 & 11.5 & 9.3 & 5.0 & 3.1 & 2.6 & 1.7 & 1.7 & 2.7 & 2.7 & 2.9 & 4.0 & 5.3 & 2.0 \\
\hline BNHS 5889 & Paratype & Female & 39.2 & 14.9 & 13.9 & 6.5 & 5.0 & 3.1 & 2.9 & 2.6 & 3.9 & 4.1 & 4.2 & 7.1 & 8.4 & 3.5 \\
\hline WILD-14-AMP-490 & Paratype & Female & 31.7 & 12.7 & 11.1 & 5.3 & 3.3 & 3.0 & 1.8 & 2.0 & 3.3 & 3.6 & 3.2 & 4.7 & 6.6 & 2.2 \\
\hline
\end{tabular}

\begin{tabular}{|c|c|c|c|c|c|c|c|c|c|c|c|c|c|c|c|}
\hline Voucher number & Type status & Gender & F2 & F3 & F4 & THL & TL & $\mathrm{ACL}$ & FOL & TFOL & $\mathrm{T} 1$ & T2 & T3 & T4 & T5 \\
\hline BNHS 5888 & Holotype & Male & 1.9 & 3.5 & 2.6 & 13.4 & 13.9 & 6.4 & 12.4 & 18.0 & 1.6 & 2.7 & 4.2 & 6.5 & 4.2 \\
\hline WILD-14-AMP-489* & Paratype & Male & 1.8 & 3.1 & 2.3 & 12.0 & 13.3 & 5.9 & 12.1 & 16.8 & 1.9 & 2.3 & 3.8 & 6.1 & 3.2 \\
\hline BNHS 5890* & Paratype & Male & 1.9 & 3.3 & 1.9 & 12.6 & 13.0 & 5.9 & 12.2 & 18.2 & 1.8 & 2.1 & 4.3 & 6.8 & 3.7 \\
\hline ZSI-WRC A/1541 & Paratype & Male & 2.0 & 3.6 & 2.6 & 11.2 & 13.3 & 6.3 & 12.5 & 17.2 & 2.1 & 2.9 & 4.5 & 7.3 & 4.3 \\
\hline WILD-14-AMP-491 & Paratype & Male & 1.8 & 3.4 & 2.6 & 13.5 & 15.0 & 6.4 & 13.5 & 20.1 & 2.1 & 2.7 & 4.3 & 7.5 & 4.4 \\
\hline BNHS 5889 & Paratype & Female & 3.1 & 5.6 & 4.1 & 20.0 & 23.2 & 11.4 & 20.7 & 30.7 & 2.9 & 4.7 & 7.4 & 12.8 & 7.4 \\
\hline WILD-14-AMP-490 & Paratype & Female & 2.2 & 4.1 & 3.7 & 17.0 & 17.6 & 9.6 & 15.2 & 21.1 & 1.7 & 4.6 & 5.4 & 8.6 & 5.5 \\
\hline
\end{tabular}

* used for genetic analysis 


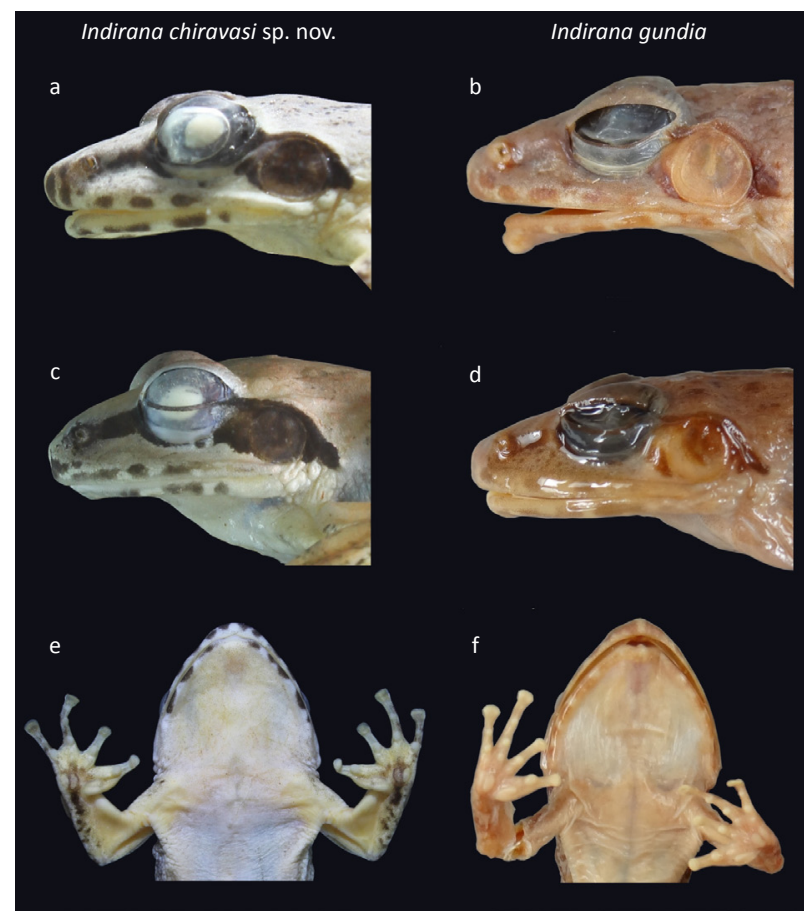

Image 3. Lateral and ventral view of head of Indirana chiravasi sp. nov.: (a) - holotype (BNHS 5888), (b) - female paratype (BNHS 5889), (c) - holotype (BNHS 5888); Indirana gundia: (d) - (male) holotype (MNHN 1985.0633), (e) - (female) paratype (MNHN 1985.0622), (f) - (male) holotype (MNHN 1985.0633). Photo credit: (a-c) Neelesh Dahanukar and (d-f) Nikhil Modak.
Description of the holotype (BNHS 5888; male) (all measurements in $\mathrm{mm}$ )

Medium-sized (SUL 27.3); head longer than wide (HL 11.4 > HW 9.8); snout longer than horizontal diameter of eye (SL $4.8>$ EL 3.7); pupil horizontal; outline of snout rounded in shape dorsally (Image 1a), truncated laterally (Image 3a); ventrally snout protruding beyond the mouth (Image 3c); nostrils nearer to snout than to the eye (SNL $2.0<$ ENL 2.7); tympanum about $3 / 4^{\text {th }}$ the diameter of eye, very close to eye; supra-tympanic fold distinct; upper eyelid width slightly more than half the horizontal diameter of eye; upper eyelids bear very few granulations; inter-narial distance almost equal to the inter-orbital distance (INL $2.6 \approx I O L 2.6$ ); canthus rostralis obtuse; loreal region slightly concave and oblique; vomerine teeth in two slightly oblique rows at the posterior border of choanae; tongue thin, bifid; bear a long mid ventral papilla.

Upper arm shorter than fore arm (UAL $5.3<$ FoAL 6.0); hand long (PAL 6.7); finger lengths from shortest to longest - F2 (1.9) < F1 (2.4) < F4 (2.6) < F3 (3.5); palmer tubercles present, outer palmer tubercle double, subarticular tubercles moderate, supernumerary tubercles present, single; nuptial pads on the sides of first finger, distinct, flat, granular; finger discs moderate
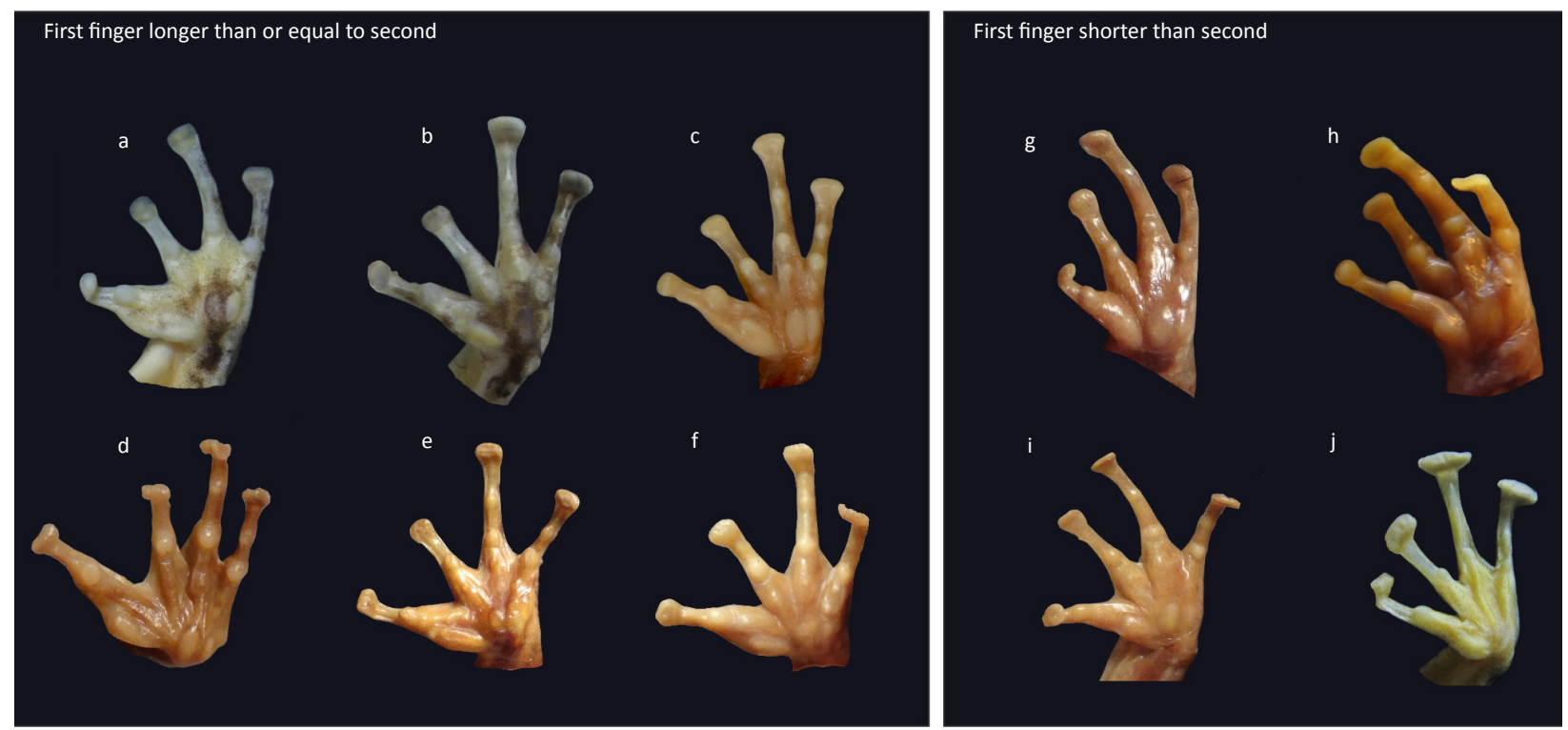

Image 4. Palms of different species of Indirana showing the distinction between first finger longer than or equal to second and first finger shorter than second. (a) Indirana chiravasi sp. nov. holotype, (b) I. chiravasi sp. nov. female paratype, (c) I. gundia Holotype (MNHN 1985.0633), (d) I. semipalamata syntype (BMNH 1947.2.29.50), (e) I. beddomii syntype (BMNH 1947.2.27.72), (f) I. brachytarsus Paralectotype (BMNH 1947.2.2.85), (g) I. diplosticta Syntype (BMNH 1947.2.2.21), (h) I. phrynoderma Syntype (BMNH 1947.2.3.8), (i) I. leptodactyla syntype (BMNH 1947.2.29.40) and (J) I. leithii topotype (uncataloged). Photo credit: (a-b) Neelesh Dahanukar, (c-i) Nikhil Modak and (j) Anand Padhye. 


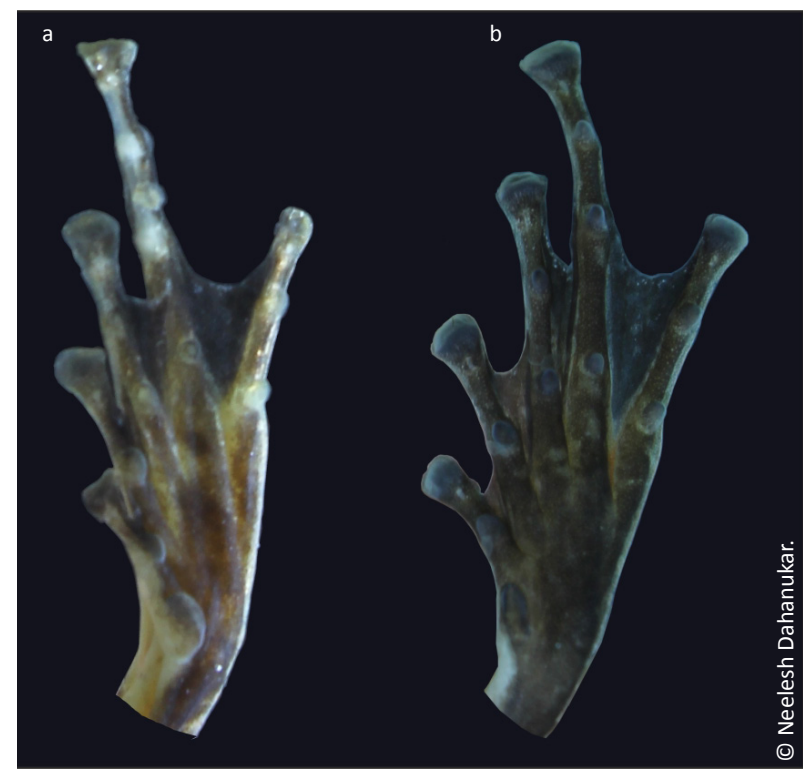

Image 5. Foot of (a) Indirana chiravasi sp. nov. holotype and (b) I. chiravasi sp. nov. female paratype.

in shape, broad, truncate, bearing semicircular groove; fingers without web or fringe of skin (Image 4a).

Hindlimbs long; thigh shorter than shank (tibia) (THL $13.4<\mathrm{TL}$ 13.9); thigh bearing distinct femoral glands, occupying posterior-ventral side of thigh; astragaluscalcaneum about half the length of foot; total foot length (including astragalus-calcaneum) longer than tibia (TFOL 18.0); toe lengths from shortest to longest

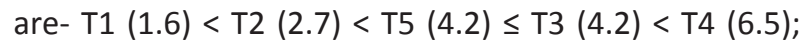
toe discs moderate; bear semicircular groove; inner metatarsal tubercle thin, elongated and shovel shaped; outer metatarsal tubercle absent; supernumerary tubercles absent; subarticular tubercles moderate; tarsal fold and outer phalangeal fringe absent; webbing formula I1-2II1-3III11/4-3IV3-11/4V (Image 5a).

Dorsal and ventral skin smooth; few longitudinal folds on dorsal side; lateral side granular.

\section{Description of female paratype (BNHS 5889) (all measurements in $\mathrm{mm}$ )}

Medium-sized (SUL 39.2); with head longer than wide (HL 14.9 > HW 13.9); snout longer than eye (SL 6.5 > EL 5.0); outline of snout rounded in shape dorsally (Image $2 a)$; truncated laterally (Image $3 b$ ); ventrally protruding beyond the mouth (Image $2 b$ ); nostrils nearer to snout than to the eye (SNL $2.6<$ ENL 3.9); tympanum about $2 / 3^{\text {rd }}$ the diameter of eye, slightly more apart from eye than in male; supra-tympanic fold distinct; upper eyelid width slightly more than half the horizontal diameter of eye; upper eyelid bearing very few granulations; inter- narial width slightly narrower than inter-orbital distance (INL $4.1<$ IOL 4.2); canthus rostralis obtuse; loreal region slightly concave and oblique; vomerine teeth in two slightly oblique rows at the posterior border of choanae; tongue thin, bifid; bearing a long mid-ventral papilla.

Upper arm shorter than fore arm (UAL 7.1 < FoAL 8.4); hand about $1 / 5^{\text {th }}$ of SUL; finger lengths from shortest to longest - F2 (3.1) < F1 (3.5) < F4 (4.1) < F3 (5.6); palmer tubercles present, outer palmar tubercle double; subarticular tubercles moderate; all supernumerary tubercles present, single; finger discs moderate in shape, broad, truncate, bearing semicircular groove; fingers without web or fringe of skin (Image 4b).

Hindlimb long, thigh shorter than tibia (THL $20.0<$ TL 23.2); astragalus-calcaneum about half the length of foot; total foot length (including astragalus-calcaneum) longer than tibia; toe lengths in order of T1 $(2.9)<\mathrm{T} 2$ (4.7) < T5 (7.4) $\leq \mathrm{T} 3(7.4)<\mathrm{T} 4$ (12.8); toe discs moderate; bear semicircular groove; inner metatarsal tubercle thin, long; outer metatarsal tubercle absent; supernumerary tubercles absent; subarticular tubercles moderate; tarsal fold and outer phalangeal fringe absent; webbing formula I1-2II1-21/2III1/1/4-3IV3-11/4V (Image 5b).

Dorsal and ventral skin smooth; few longitudinal folds on dorsal side; lateral side granular.

\section{Colouration}

Male: Dorsal colour grey to brown in preservation (Image 1) and olive brown with scattered yellow markings in living specimen (Image 6) with W-shaped marking comprising of densely organized black spots; black strip running from tip of snout to shoulder through eye and tympanum; creamy white band across head between upper eyelids usually present followed posteriorly by a dark band; in life, olive green to brown band running from above shoulder to groin (Image 6); forelimb bearing transverse bands also on fingers; palm dark brown in colour at least in live condition; brown bars on thigh, tibia, outer side of foot and dorsal surface of toes; ventral and inner side of foot dark brown in colour up to tibiotarsal articulation; ventrally white with few melanophores visible only under magnification.

Female: General appearance as in male. Dorsally more pale than male without W-shaped marking (Image 2); darker flanks; limbs with dark cross bars in life, faded in preservation.

\section{Sexual Dimorphism}

Tympanum about $3 / 4^{\text {th }}$ the diameter of eye in male and $2 / 3^{\text {rd }}$ the diameter of eye in female. Tympanum very close to eye in male and slightly farther apart in female 


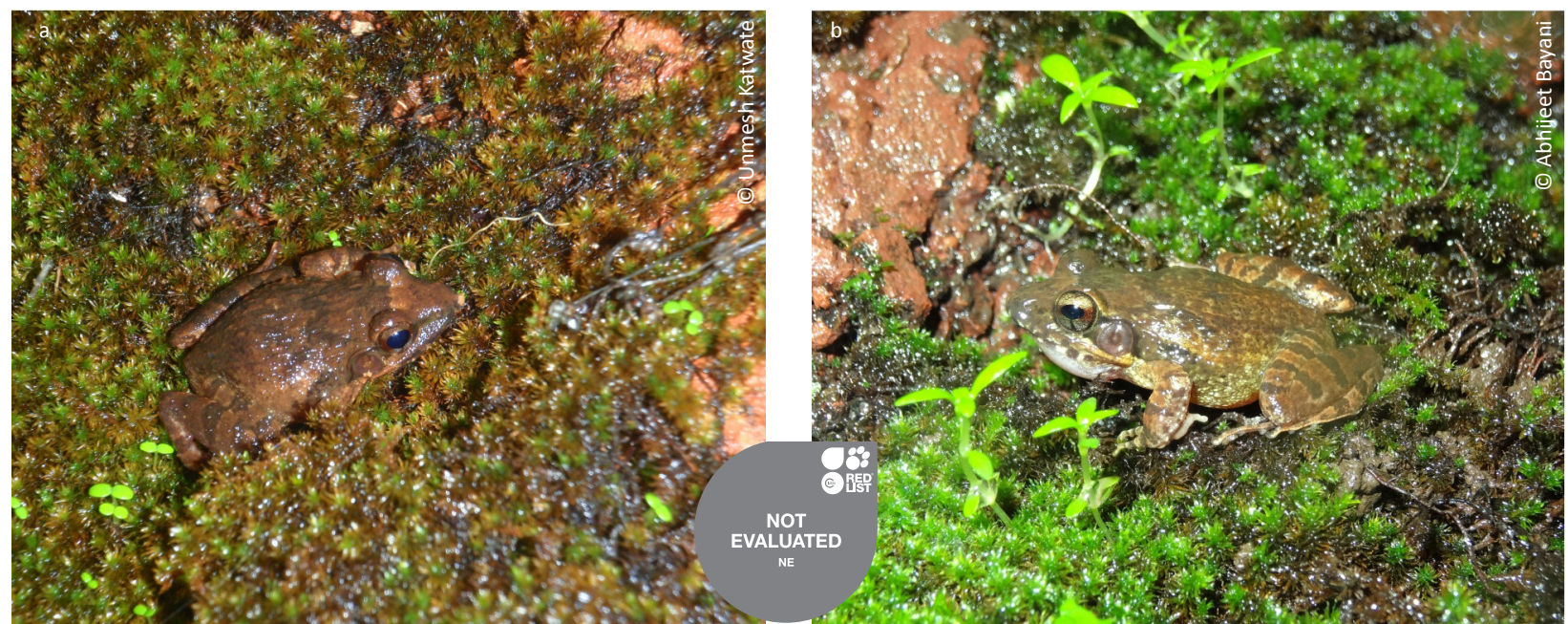

Image 6. Indirana chiravasi sp. nov. in life (a) paratype (BNHS 5890) and (b) paratype (WILD-14-AMP-491).

(Image 3). Inner metatarsal tubercle thin and shovelshaped in male while slightly thicker and long in female (Image 5). Webbing formula I1-2II1-3III11/4-3IV3-11/4V in male and $|1-2|\left|1-2 \frac{1}{2}\right| \| 1 \frac{1}{4}-3 \mid V 3-1 \frac{1}{4} \mathrm{~V}$ in female. Breeding males show single internal vocal sac that is visible only during calling (Appendix B); bearing nuptial pad on the outer side of first finger and femoral glands on thighs; mature eggs visible from transparent latero-ventral skin of breeding females.

\section{Etymology}

The specific epithet, a combination of words 'chir' (singular) or 'chira' (plural) which means crevice or crevices in Marathi and 'vasi' in Sanskrit means 'inhabitant of', which emphasizes crevice dwelling habit of this species. The specific name is noun in apposition.

\section{Distribution}

The species is currently known only from its type locality at Amboli $\left(15.956^{\circ} \mathrm{N} \& 73.997^{\circ} \mathrm{E} ; 744 \mathrm{~m}\right)$, which is a small hill station in the southwestern Maharashtra, India (Fig. 1).

\section{Habitat}

The species occupies lateritic rocky outcrops (Image 7a). It is often found in the crevices of the laterite boulders (Image 7b). Males were mostly seen while calling from the wet rocks or boulders covered with mosses. Females were collected from under the log in the forest and from under the roadside stone.

\section{Natural history and description of tadpoles}

Eggs were seen laid under the mosses on lateritic wet rocks and boulders (Image 8). Hatchlings remain at the egg laying site (Image 9a). Embryos, hatchlings and tadpoles of two different stages were observed in the same habitat. Unhatched eggs (Images 8a,b) show the embryos with external gills, parallel to stage 20 (Gosner 1960). Tadpoles were seen on wet boulders feeding on algal matter (Image 9). Image 9a shows hatchlings, parallel to stage 25 (Gosner 1960). Image 9b shows tadpole in its terrestrial habitat with fully developed hind limbs (without forelimb), parallel to stage 40 (Gosner 1960). Image 9c shows terrestrial tadpoles with long, finless tail which is not under resorption, oral apparatus and fully developed forelimbs as well as hind limbs, parallel to stage 42 (Gosner 1960). Image 9d shows stage 44 (Gosner 1960) with mouth beneath eye and greatly reduced tail, while image 9 e shows stage 46 (Gosner 1960) - a completely metamorphosed froglet.

Tadpoles showed semi-condensed individual keratodont formula (Dubois 1994) as $4\left[\mathrm{~A}_{1}-\mathrm{A}_{4}\right] / 4\left[\mathrm{P}_{1}-\mathrm{P}_{2}\right]$. The oral apparatus is divided into two lateral parts by large horny beak. The first anterior keratodont ridge $A_{1}$ is divided while three succeeding anterior keratodont ridges $A_{2}-A_{4}$ are placed lateral to the horny beak. On the posterior labia first keratodont ridge $P_{1}$ is marginal, present on the either sides, while the second one $-\mathrm{P}_{2}$ is placed lateral to the horny beak. Third and fourth keratodont ridges $-\mathrm{P}_{3}$ and $\mathrm{P}_{4}$ are continuous. Although, the ridge $P_{3}$ appears to be divided into four subunits the keratodont rows are continuous on it (Image 10).

\section{Common name}

Amboli Leaping Frog. 

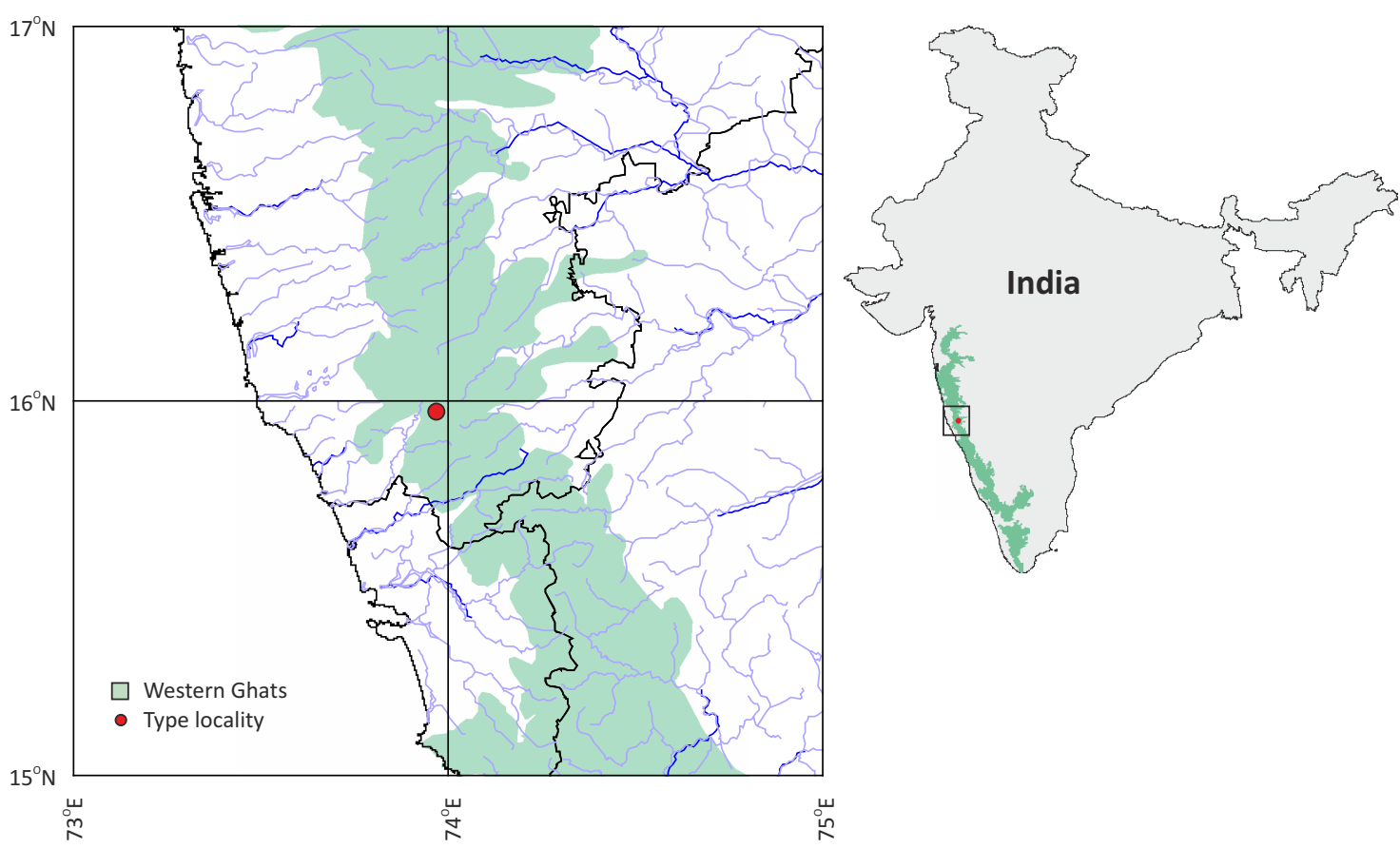

Figure 1. Type locality of Indirana chiravasi sp. nov.
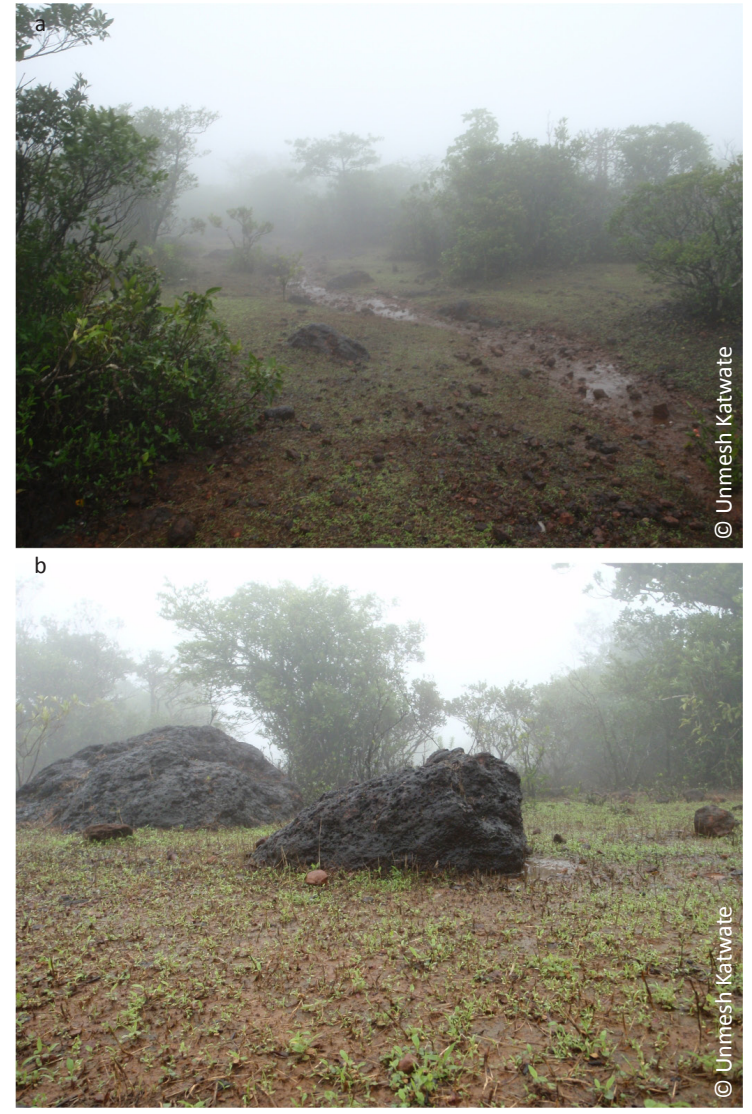

Image 7. Habitat at type locality of Indirana chiravasi sp. nov. during monsoon season. (a) General habitat on lateritic plateau and

(b) lateritic rocks where adults, eggs and tadpoles are found in crevices and moss covered surfaces.
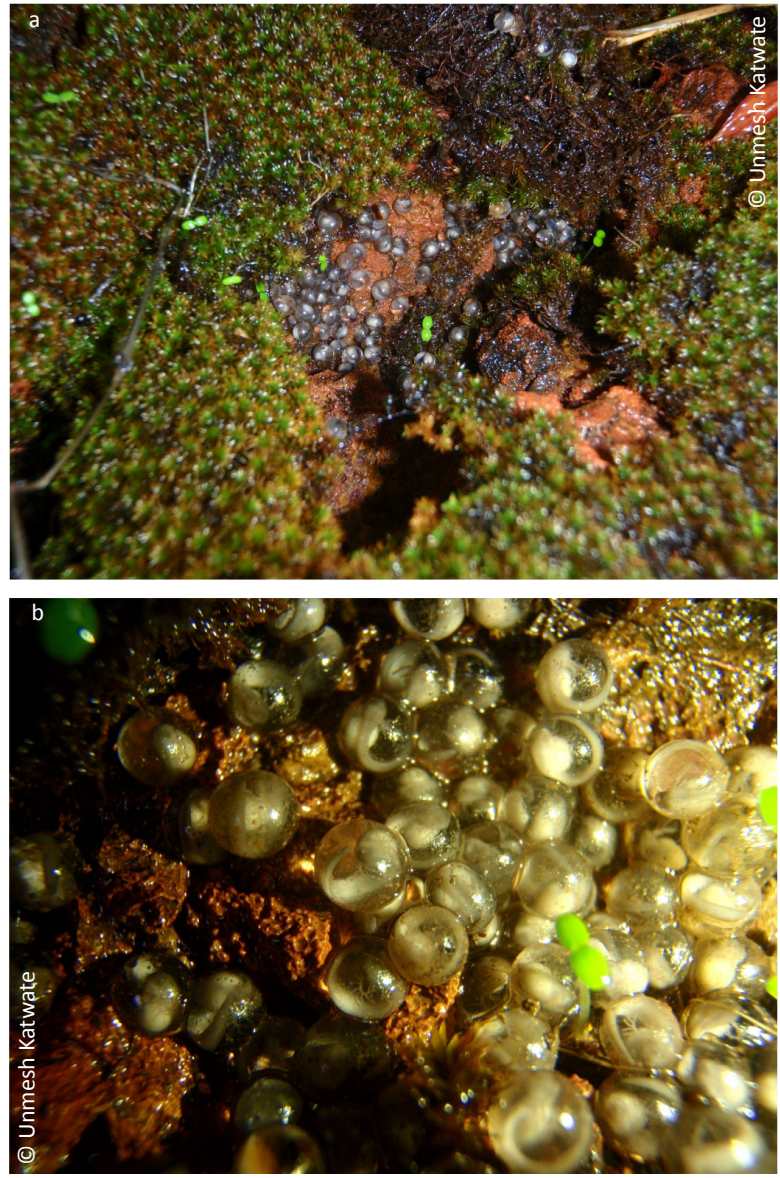

Image 8. Eggs of Indirana chiravasi sp. nov. laid in the moss on a lateritic rock. 

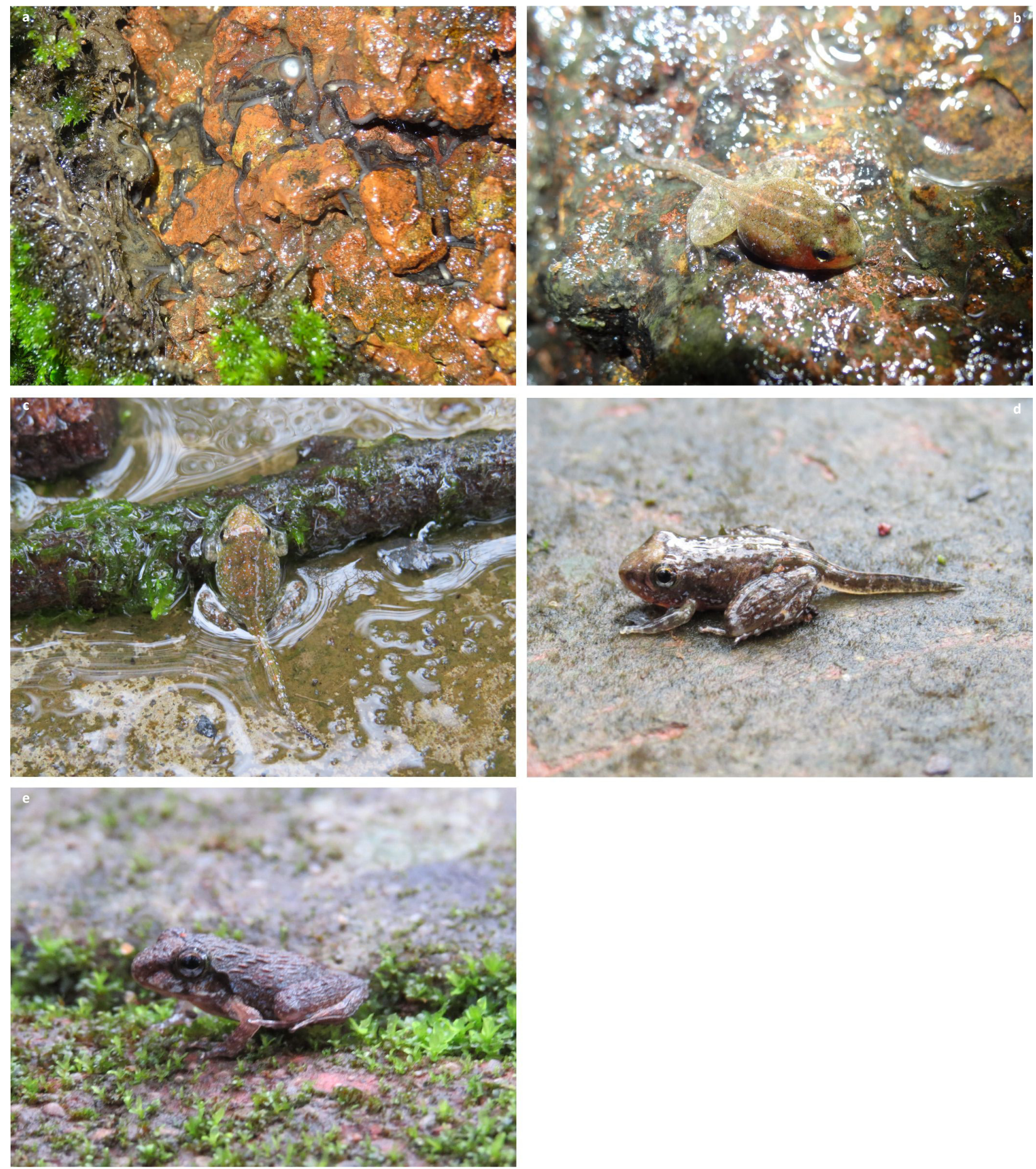

Image 9. Indirana chiravasi sp. nov. hatchlings and egg (a), early phase tadpoles without forelimb (b), late phase tadpoles with fore limbs (c) and different stages in tail regression and completion of metamorphosis (d-e). Photo credit: (a, b) Abhijeet Bayani and (c-e) Avishkar Munje.

\section{Statistical analysis}

Size corrected morphometric data was not significantly different from multivariate normal (Doornik \& Hansen omnibus, $E p=67.14, P=0.0561$ ). MANOVA suggested that all species formed significantly distinct clusters (Pillai's trace $=5.001, F_{208,216}=1.86, \mathrm{P}$
$<0.0001$ ). First three canonical axes explained $86.81 \%$ of the total variation in the data where the first axis explained $43.89 \%$, second axis explained $25.39 \%$ and third axis explained $17.54 \%$ of the total variation. First two canonical axes separated Indirana chiravasi sp. nov. from I. beddomii, I. diplosticta, I. leithii, I. leptodactyla 


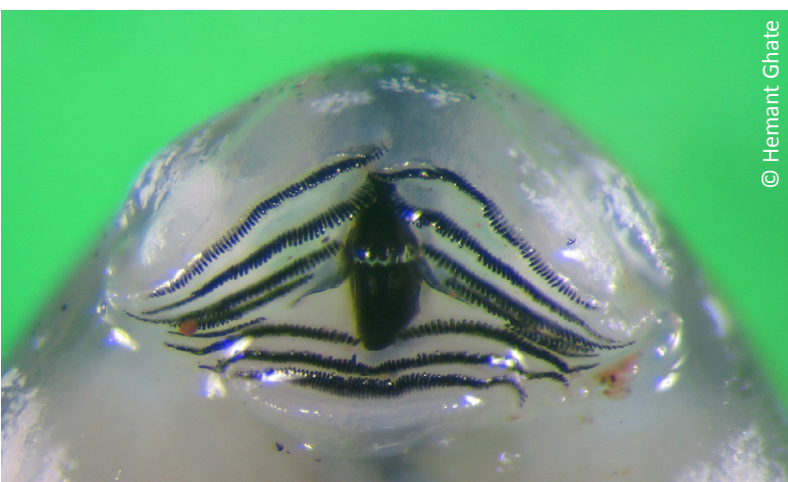

Image 10. Oral disc of Indiana chiravasi sp. nov. tadpole.

and I. phrynoderma (Fig. 2a). Indirana chiravasi sp. nov. was separated from I. brachytarsus, I. gundia and I. semipalmata on the third canonical axis (Fig. 2b). CVA loadings of morphometric characters on the first three canonical axes are shown in Table 3. Characters such as ENL, INL, F3, F4, TL, ACL, FOL, T1 and T2 separated Indirana chiravasi sp. nov. from other related species.

\section{Genetic analysis}

Concatenated genetic sequences of mitochondrial $12 \mathrm{~S}$ and $16 \mathrm{~S}$ genes and nuclear rho and rag1 genes had total 1342 bases. Best fit model for the nucleotide substitution was general time reversal model with gamma distribution and invariant sites $(\mathrm{GTR}+\mathrm{G}+\mathrm{I}, \mathrm{AIC}=$ 10516.66, $\mathrm{InL}=-5157.33, \mathrm{G}=0.39, \mathrm{I}=0.34, d f=101, \mathrm{n}=$ 1342). Maximum likelihood analysis of the genetic data (Fig. 3) suggested that Indirana chiravasi sp. nov. formed a monophyletic group genetically distinct from the other Indirana species for which genetic data are available.

\section{Comparison with other species of Indirana}

Indirana chiravasi differs from I. diplosticta, I. leithii, I. leptodactyla, I. longicrus and I. phrynoderma in having first finger equal to or longer than second finger (vs. first finger shorter than second) (Image 4). Furthermore, I. chiravasi has moderate webbing (I1-2||1-3III11/4-3IV3$\left.1 \frac{1}{4} \mathrm{~V}^{*}\right)$ vs. reduced webbing $\left(|2-2||2-3||| 2 \frac{1}{2}-4 \mid \mathrm{V} 4-2 \frac{1}{2} \mathrm{~V}\right.$ in I. diplosticta; I1-2II2-3III3-4IV4-3V in I. phrynoderma and $\left|1-2 \frac{1}{4}\right||2-3||| 3-4 \mid V 4-3 \mathrm{~V}$ in I. leptodactyla); distinct canthus rostralis (vs. indistinct canthus rostralis in $I$. phrynoderma); smooth skin with glandular folds (vs. warty skin in I. phrynoderma), presence of double outer palmer tubercle (vs. single outer palmer tubercle in I. leithii); vomerine teeth in two oblique series at the posterior border of choanae and long midventral lingual papilla (vs. vomerine teeth none and tongue without papilla in I. longicrus) and tympanum $2 / 3^{\text {rd }}$ (in female) to
Table 3. CVA loadings of morphometric characters on the first three canonical axis.

\begin{tabular}{|c|c|c|c|}
\hline & Axis 1 & Axis 2 & Axis 3 \\
\hline $\mathrm{HL}$ & -0.030 & -0.320 & -0.330 \\
\hline HW & -0.220 & -0.120 & -0.190 \\
\hline SL & 0.031 & -0.090 & -0.190 \\
\hline EL & -0.040 & -0.200 & -0.040 \\
\hline TYL & 0.122 & -0.400 & -0.180 \\
\hline UEW & -0.050 & 0.042 & 0.042 \\
\hline SNL & -0.100 & -0.030 & 0.072 \\
\hline ENL & 0.069 & -0.030 & -0.200 \\
\hline INL & -0.200 & 0.017 & 0.079 \\
\hline IOL & -0.120 & -0.060 & -0.180 \\
\hline UAL & -0.350 & 0.181 & -0.020 \\
\hline FoAL & -0.100 & 0.049 & -0.210 \\
\hline F1 & 0.167 & 0.144 & -0.110 \\
\hline F2 & 0.095 & 0.313 & 0.168 \\
\hline F3 & 0.135 & 0.345 & -0.090 \\
\hline F4 & 0.109 & 0.331 & 0.061 \\
\hline THL & -0.360 & 1.076 & -0.410 \\
\hline TL & -0.430 & 1.351 & -0.470 \\
\hline $\mathrm{ACL}$ & -0.330 & 0.680 & -0.280 \\
\hline $\mathrm{FOL}$ & -0.150 & 1.387 & -0.540 \\
\hline TFOL & -0.460 & 2.016 & -0.810 \\
\hline $\mathrm{T} 1$ & 0.132 & 0.222 & -0.020 \\
\hline T2 & 0.033 & 0.292 & -0.150 \\
\hline T3 & -0.010 & 0.521 & -0.180 \\
\hline T4 & 0.017 & 0.914 & -0.380 \\
\hline T5 & 0.178 & 0.543 & -0.150 \\
\hline
\end{tabular}

$3 / 4^{\text {th }}$ (in male) the diameter of eye (vs. tympanum half the diameter of eye in I. longicrus). Raw genetic distance between I. chiravasi and I. leptodactyla (as identified by Nair et al. 2012 b) is $23.9 \%$ for 16 S gene and $12.3-12.7$ $\%$ for all the genes together; between $I$. chiravasi and $I$. diplosticta (as identified by Nair et al. 2012b) is 9.1-11.0 $\%$ for $16 \mathrm{~S}$ gene and $4.2-4.7 \%$ for all the genes together; and between I. chiravasi and I. leithii (topotypic material from Modak et al. 2014) is $12.5-12.8 \%$ for 16 S gene and 6.9-7.3\% for all the genes together.

The whereabouts of the type specimen of Indirana tenuilingua described by are not known and is suggested to be lost (Dubois 1984). Therefore, for the comparison of the new species with $I$. tenuilingua, we have relied on the original description by Rao (1937). Indirana chiravasi differs from $I$. tenuilingua in having head longer than broad (vs. head slightly wider than long), inter-orbital 

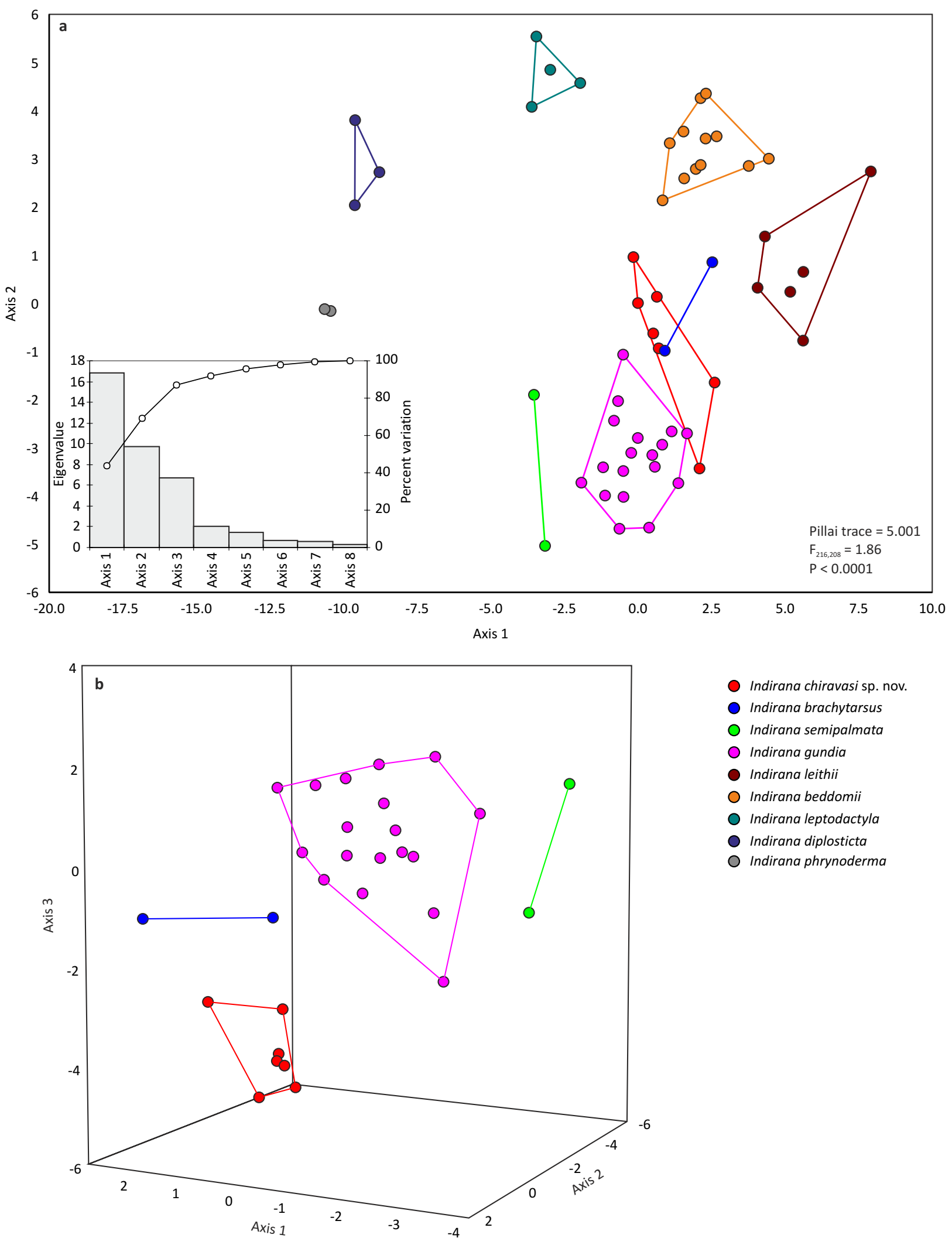

- Indirana chiravasi sp. nov.

- Indirana brachytarsus

O Indirana semipalmata

O Indirana gundia

- Indirana leithii

O Indirana beddomii

- Indirana leptodactyla

- Indirana diplosticta

- Indirana phrynoderma

Figure 2. Multivariate Analysis of Variance - Canonical Variates Analysis (MANOVA-CVA) of morphometric data of Indirana species. (a) CVA on first two canonical axes, scree plot is shown in the inset, and (b) CVA on first three canonical axes for morphometrically closely related species to Indirana chiravasi sp. nov. 


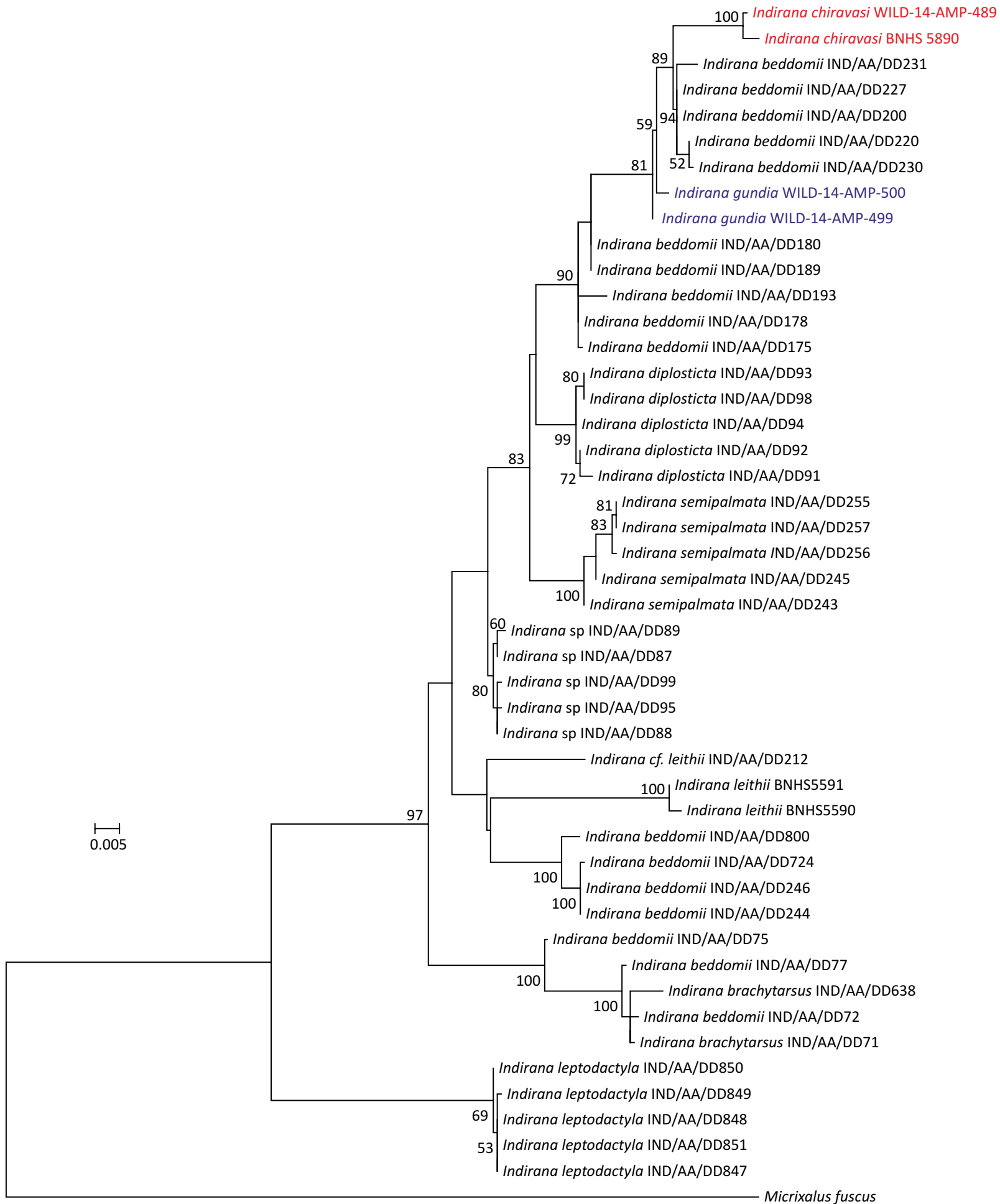

Figure 3. Maximum likelihood phylogenetic analysis of Indirana based on mitochondrial $12 \mathrm{~S}$ and $16 \mathrm{~S}$ genes and nuclear rho and rag1 genes. Best fit model for the nucleotide substitution was general time reversal model with gamma distribution and invariant sites $(\mathrm{GTR}+\mathrm{G}+\mathrm{I}$, AIC $=$ $10516.66, \ln \mathrm{L}=-5157.33, \mathrm{G}=\mathbf{0 . 3 8 5}, \mathrm{I}=\mathbf{0 . 3 4 0}$ ). There were total 1342 bases in final matrix. Micrixalus fuscus is used as an outgroup. Numbers at the node are percent bootstrap values for 1000 iterations. 
distance equal to or wider than inter-narial distance (vs. interorbital width more than twice the distance between the nostrils) and toes and fingers with deep semicircular groove (vs. semicircular groove in front of the toes and fingers absent, faint or indistinct).

Indirana chiravasi differs from I. semipalmata in having broader head (35.2-36.4\% SUL vs. 33.6-33.7 $\%$ SUL), tympanum $2 / 3^{\text {rd }}$ (in female) to $3 / 4^{\text {th }}$ (in male) the diameter of eye (vs. tympanum equal to or larger than eye in male and slightly smaller in female) and moderately webbed toes with the webbing formula I12|| $1-3||\left|1 \frac{1}{4}-3\right| V 3-1 \frac{1}{4} \mathrm{~V}$ in male and I1-2II1-21/2III1 $\frac{1}{4}-3 \mid \mathrm{V} 3$ $11 \frac{1}{4} \mathrm{~V}$ in female (vs. half webbed toes with the webbing formula I2-2II2-3III2-31/4IV31/4-2V I both the sexes). Raw genetic distance between I. chiravasi and I. semipalmata (as identified by Nair et al. 2012b) is $7.4-8.4 \%$ for $16 \mathrm{~S}$ gene and $4.1-4.3 \%$ for all the genes together.

Indirana chiravasi differs from I. beddomii in having smaller finger 2 length (7.0-7.9 \% SUL vs. 8.3-10.5\% SUL), webbing formula I1-2II1-3III1/4-3IV3-11/4V in male and $|1-2|\left|1-2 \frac{1}{2}\right||| 1 \frac{1}{4}-3 \mid V 3-1 \frac{1}{4} \mathrm{~V}$ in female (vs. webbing formula, I1-2II1-2III-3IV3-1V, in both males and females) and long, thin, shovel-shaped inner metatarsal tubercle (vs. long and stout inner metatarsal tubercle). Genetic difference between I. chiravasi and I. beddomii cannot be determined as Nair et al. (2012b) have considered several genetically distinct populations as members of $I$. beddomii species complex.

Indirana chiravasi can be distinguished from I. brachytarsus in having few longitudinal folds on dorsal side (vs. numerous longitudinal folds on dorsal side), thin, shovel-shaped inner metatarsal tubercle (vs. long and stout inner metatarsal tubercle) moderate webbing (vs. extensive webbing, webbing formula, |1-2||1-21/2III3IV3-1V) and having broader head (35.2-36.4\% SUL vs. $33.1-34.6 \%$ SUL). Furthermore, if the identification of $I$. brachytarsus by Nair et al. (2012b) is correct then the two species are also genetically quite distinct (Fig. 3). Raw genetic distance between I. chiravasi sp. nov. and $I$. brachytarsus (as identified by Nair et al. 2012b) is $11.6 \%$ for $16 \mathrm{~S}$ gene and $8.0-8.3 \%$ for all the genes together.

Indirana chiravasi sp. nov. differs from I. gundia in the most prominent feature of having a single internal vocal sac (vs. bilateral vocal sacs). The presence of bilateral vocal sac in I. gundia not only appears in the original description (Dubois 1986) but they can also be seen in two patches on the ventral side of the head (Image 3f). Furthermore, I. chiravasi sp. nov. differs from I. gundia in having the webbing formula I1-2II1-3III11/4-3IV3-11/4V in male and $|1-2|\left|1-2 \frac{1}{2}\right||| 1 \frac{1}{4}-3 \mid \mathrm{V} 3-1 \frac{1}{4} \mathrm{~V}$ in female (vs. webbing formula, I1-2II1-21/2III-3IV3-1V, in both males and females) and inner metatarsal tubercle thin shovelshaped (vs. distinct and stout). Morphometrically (Fig. 2 ) both the species form significantly distinct clusters (Fisher's distance $=3.142, \mathrm{P}=0.004$ ). Raw genetic distance between I. chiravasi sp. nov. and I. gundia is 5.2-5.5\% for $16 \mathrm{~S}$ gene and $2.8-3.1 \%$ for all the genes together.

\section{DISCUSSION}

Indirana chiravasi sp. nov. forms the eleventh species in the Western Ghats endemic genera Indirana and monotypic family Ranixalidae. Phylogenetic analysis of Indirana species based on two mitochondrial and two nuclear genes suggests that, I. chiravasi forms a monophyletic group with topotypic I. gundia and five specimens (IND/AA/DD/CC 200, 220, 227, 230 and 231) of $I$. beddomii species complex (as identified by Nair et al. 2012b).

Both morphologically and genetically, Indirana gundia is one of the close congeners of I. chiravasi. However, apart from the morphological variations, there was a significant difference in the multivariate morphometric analysis of the two species. Further, the two species are separated by a genetic difference of $5.2-5.5 \%$ for $16 \mathrm{~S}$ gene. Based on the suggestions of Vences et al. (2005) the high genetic divergence in $16 \mathrm{~S}$ gene validates that $I$. chiravasi is a distinct species. Further, based on the current distribution records, these two species are separated by a geographical distance of more than $400 \mathrm{~km}$. Genetic data for I. gundia is provided for the first time in the current study. This data is based on topotypic material (Image 11), for which the species identity is confirmed by its morphological comparison with type series as well as morphometric analysis. The two specimens of $I$. gundia did not form a monophyletic group, although there was only $0.3 \%$ genetic distance considering all genes together and $0.2 \%$ genetic distance in 165 gene. This could be attributed to small sample size (only two specimens) in the current study and further genetic analysis with additional samples may reveal within species variation in I. gundia.

Based on the phylogenetic analysis (Fig. 3) five specimens (IND/AA/DD/CC 200, 220, 227, 230 and 231) of Indirana beddomii species complex (as identified by Nair et al. 2012b) form a monophyletic group and fall between I. chiravasi and I. gundia. This cluster is separated from $I$. chiravasi by raw genetic distance of $3.5-3.9 \%$ and from I. gundia by $3.6-3.9 \%$ in $16 \mathrm{~S}$ gene. However, because of the lack of information 

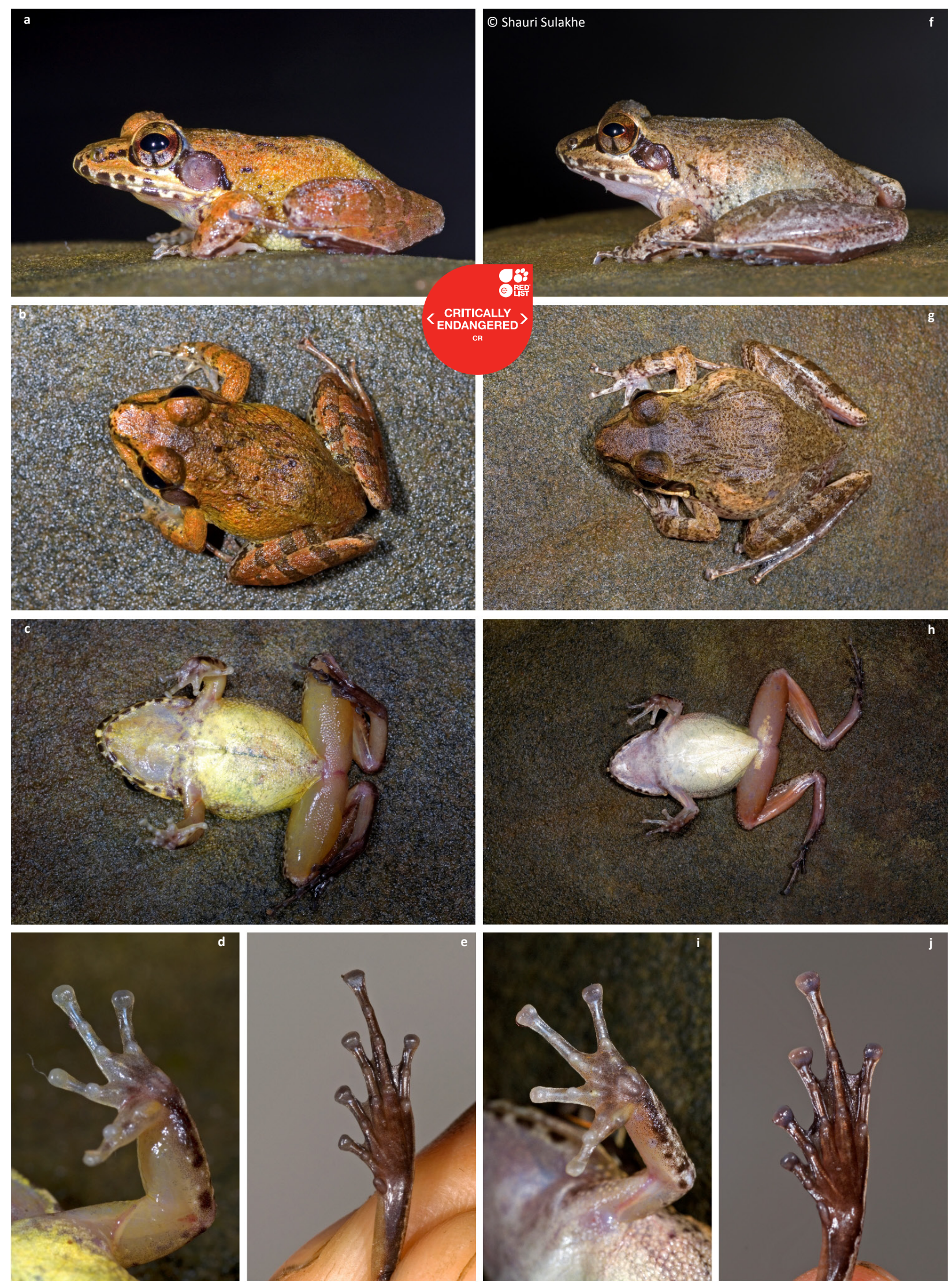

Image 11. Topotypic Indirana gundia male (a-e) and female (f-j) in life. WILD-14-AMP-499 (Male) and WILD-14-AMP-500 (female), Gundia, Karnataka. 
on the collection locality as well as details of museum deposition, we could not compare these specimens with I. chiravasi. Nevertheless, it should be noted that both $I$. chiravasi and I. gundia are morphologically distinct from any of the syntypes of $I$. beddomii.

Despite of the above mentioned lacunae, Nair et al. (2012b) have provided genetic data for a wide distribution of Indirana populations in southern Karnataka, Kerala and Tamil Nadu. Further, Modak et al. (2014) have provided details for Indirana leithii based on topotypic material and a wide distribution in the northern Western Ghats. As a result genetic data from Nair et al. (2012b) and Modak et al. (2014) forms a good comparative material for assessing the affinities between I. chiravasi and other populations of Indirana sp. nov. from a wide geographic range within the Western Ghats.

Recent documentation of primitive breeding in Indirana species from Amboli by Gaitonde \& Giri (2014) actually refers to the breeding biology of I. chiravasi based on the photographs provided by Gaitonde \& Giri (2014).

Further, according to our extensive survey records, there is no other species of Indirana present in Amboli. Gaitonde \& Giri (2014) have provided a detailed account of courtship and breeding bahaviour of the species along with the fertilization success. However, they do not provide the information on developmental stages.

Our observations, therefore, complete the information on breeding and developmental cycle of the species. Although we have provided developmental stages of this species parallel to the stages suggested by Gosner (1960), it is essential to note that the development and metamorphosis of the genus Indirana is different from the general ranid pattern, as the tadpoles do not have tail fins and are semi-terrestrial (Dubois 1986; Gaitonde \& Giri 2014; Modak et al. 2014). The developmental stages of Indirana chiravasi sp. nov. differs from the stages in Gosner (1960) as follows. The unhatched eggs with embryo of $l$. chiravasi sp. nov. showed presence of external gills. This stage is parallel to stage 20 of Gosner (1960). However, hatching does not occur at this stage. It should be noted that in $I$. chiravasi, hatching does not occur until the development of operculum, which is a stage parallel to stage 25 of Gosner (1960). Further, the semi terrestrial tadpole with oral apparatus, full tail without any regression and fully developed forelimb (stage 42 of Gosner 1960) persists for a long duration. In I. chiravasi, tadpole of this stage continues to feed in its terrestrial habitat for around a month after which metamorphosis completes.
This is unlike the classical metamorphosis described by Gosner (1960) where in on complete development of fore limb there is onset of metamorphosis with changes such as the beginning of tail regression, oral apparatus starts disappearing leading to formation of adult like mouth and metamorphosis is essentially completed within a short duration. These subtle differences in the development of $I$. chiravasi from the pattern provided by Gosner (1960), calls for the detailed study of developmental patterns in Western Ghats endemic genera such as Indirana.

Description of the new species Indirana chiravasi, and previous suggestions that there are species complexes and undescribed species (Nair et al. 2012a, 2012b; Modak et al. 2014), suggests that especially for an endemic and monotypic family such as Ranixalidae, the Western Ghats are subject to Linnean shortfall (Bini et al. 2006). Out of the 10 known species of this genus, Indirana gundia and I. phrynoderma are Critically Endangered; I. brachytarsus, I. leptodactyla and $I$. diplosticta are Endangered; I. leithii is Vulnerable; I. longicrus and I. tenuilingua are Data Deficient; and I. beddomii and I. semipalmata are Least Concern (IUCN 2014). With high proportion of threatened species within this endemic family, there is immediate concern for conservation initiatives. Therefore, further studies to resolve taxonomic status of species complexes and understanding their distribution patters are essential. Moreover, additional information on ecology and natural history would help in designing conservation strategies.

\section{Comparative Material}

Indirana beddomii: Syntype, BMNH 1947.2.27.72 (Female), Syntype, BMNH 1947.2.27.82 (female), Syntype, BMNH 1947.2.27.83 (Male), Syntype, BMNH 1947.2.27.85 (female), 4 exs., Malabar, coll. Col. Beddome; Syntypes, BMNH 1947.2.27.89-91 (females), 3 exs. Anamallays (=Annamalai), coll. Col. Beddome; Syntype, BMNH 1947.2.4.86 and 87 (females), BMNH 1947.2.4.88 (Male), 3 exs., Sevagherry (=Sivagiri, Tamil Nadu), coll. Col. Beddome; Syntype, BMNH 1947.2.27.87 (female), Syntype BMNH 1947.2.27.88 (Male), 2 exs., Travancore, coll. Col. Beddome.

Indirana brachytarsus: Lectotype, BMNH 1947.2.27.92 (Female), 1 ex., Anamallays (=Annamalai), coll. Col. Beddome; Paralectotype, BMNH 1947.2.2.85 (female), 1 ex., Sevagherry (=Sivagiri, Tamil Nadu), coll. Col. Beddome.

Indirana diplosticta: Syntypes, BMNH 1947.2.2.21 and 23 (females), 2 exs., Malabar, coll. Col. Beddome; 
Syntype, BMNH 1947.2.2.22 (male), 1 ex., Malabar, coll. Col. Beddome.

Indirana gundia: Holotype, MNHN 1985.0633 (Male), 26.vii.1984, 1 ex., Gundia, forêt de Kemphole, à l'ouest de Sakleshpur, Karnataka, Inde (Gundia, Kemphole forest, west of Sakleshpur, Karnataka, India), coll. A. Dubois; Paratypes, MNHN 1985.0596 (male), 24.vii.1984, 1 ex., MNHN 1985.0599, MNHN 1985.0603, MNHN 1985.0605, MNHN 1985.0608, 1985.0610 and MNHN 1985.0628 (males), 26.vii.1984, 6 exs.; MNHN 1985.0637-0638 (females), 26.vii.1984, 2 exs., MNHN 1985.0611, MNHN 1985.0617-0620 and MNHN 1985.0622 (females), 27.vii.1984, 6 exs., Gundia, forêt de Kemphole, à l'ouest de Sakleshpur, Karnataka, Inde (Gundia, Kemphole forest, west of Sakleshpur, Karnataka, India), coll. A. Dubois. Topotype, WILD-14AMP-499 (Male), 1 ex., 29.vii.2014, Gundia, Karnataka $\left(12.825^{\circ} \mathrm{N} \& 75.569^{\circ} \mathrm{E}, 128 \mathrm{~m}\right)$, coll. A. Padhye, N. Modak and S. Sulakhe; Topotype WILD-14-AMP-500 (female), 1 ex., 29.vii.2014, Gundia, Karnataka $\left(12.829^{\circ} \mathrm{N}\right.$ \& $\left.75.607^{\circ} \mathrm{E}, 224 \mathrm{~m}\right)$, coll. A. Padhye, N. Modak and S. Sulakhe.

Indirana leithii: Topotypes, BNHS 2830-31, BNHS 2833, BNHS 2838-39 (females), 8.viii.1991, 5 exs., Matheran, Mumbai, India, coll. A.G. Sekar and V. Hegde; Topotype, BNHS 5590 (Female), 30.ix.12, 1 ex., Matheran, Mumbai, India, coll. N. Modak and A. Bayani.

Indirana leptodactyla: Syntype, BMNH 1947.2.29.39-

40 (females), 2 exs., Malabar, coll. Col. Beddome; Syntype BMNH 1947.2.29.41 (Male), 1 ex., Malabar, coll. Col. Beddome; Non-Type, BMNH 1897.1.10.11 (female), 1 ex. Devicolum, Travancore, 1,219-2,133 m, coll. Fergusson.

Indirana phrynoderma: Syntypes, BMNH 1947.2.3.89 (males), 2 exs., Anamallays (=Annamalai), coll. Col. Beddome.

Indirana semipalmata: Syntype, BMNH 1947.2.29.50 (female), 1 ex., Malabar, coll. Col. Beddome; Syntype, BMNH 1947.2.29.51 (male), 1 ex., Malabar, coll. Col. Beddome.

Data for I. longicrus and I. tenuilingua from Rao (1937) as the type specimens are missing and are suggested to be lost (Dubois 1984)

\section{REFERENCES}

Altschul, S.F., W. Gish, W. Miller, E.W. Myers \& D.J. Lipman (1990). Basic local alignment search tool. Journal of Molecular Biology 215: 403-410; http://dx.doi.org/10.1016/S0022-2836(05)80360-2

Biju, S.D., I. van Bocxlaer, S. Mahony, K.P. Dinesh, C. Radhakrishnan, A. Zachariah, V. Giri \& F. Bossuyt (2011). A taxonomic review of the
Night Frog genus Nyctibatrachus Boulenger, 1882 in the Western Ghats, India (Anura: Nyctibatrachidae) with description of twelve new species. Zootaxa 3029: 1-96.

Biju, S.D. \& F. Bossuyt (2003). New frog family from India reveals an ancient biogeographical link with the Seychelles. Nature 425: 711714; http://dx.doi.org/10.1038/nature02019

Bini, L.M., J.A.F. Diniz-Filho, T.F. Rangel, R.P. Bastos \& M.P. Pinto (2006). Challenging Wallacean and Linnean shortfalls: knowledge gradients and conservation planning in a biodiversity hotspot. Diversity and Distributions 12(5): 475-482; http://dx.doi. org/10.1111/j.1366-9516.2006.00286.x

Bossuyt, F. \& M.C. Milinkovitch (2000). Convergent adaptive radiations in Madagascan and Asian ranid frogs reveal covariation between larval and adult traits. Proceedings of National Academy of Science USA 97: 6585-6590; http://dx.doi.org/10.1073/pnas.97.12.6585

Doornik, J.A. \& H. Hansen (2008). An Omnibus Test for Univariate and Multivariate Normality. Oxford Bulletin of Economics and Statistics 70: 927-939; http://dx.doi.org/10.1111/j.1468-0084.2008.00537.x

Dubois, A. (1984). Note préliminaire sur le groupe de Rana limnocharis Gravenhorst, 1829 (Amphibiens, Anoures). Alytes 3: 143-159.

Dubois, A. (1986). Diagnose préliminaire d'un nouveau genre de Ranoidea (Amphibiens, Anoures) du sud de I'Inde. Alytes 4: 113118.

Dubois, A. (1994). Keratodont formulae in anuran tadpoles: proposals for a standardization. Journal of Zoological Systematics and Evolutionary Research 32(4): 297-318; http://dx.doi. org/10.1111/j.1439-0469.1994.tb00489.x

Dubois, A. \& A. Ohler (1999). Asian and oriental toads of the Bufo melanostictus, Bufo scaber and Bufo stejnegeri groups (Amphibia, Anura): a list of available and valid names and redescription of some name-bearing types. Journal of South Asian Natural History 4(2): 133-180.

Edgar, R.C. (2004). MUSCLE: multiple sequence alignment with high accuracy and high throughput. Nucleic Acids Research 32(5): 17921797; http://dx.doi.org/10.1093/nar/gkh340

Frost, D.R., T. Grant, J. Faivovich, R.H. Bain, A. Haas, C.F.B Haddad, R.O. De Sa, A. Channing, M. Wilkinson, S.C. Donnellan, C.J. Raxworthy, J.A. Campbell, B. L. Blotto, P. Moler, R.C. Drewes, R.A. Nussbaum, J.D. Lynch, D.M. Green \& W.C. Wheeler (2006). The amphibian tree of life. Bulletin of the American Museum of Natural History Number 297: 1-291; http://dx.doi.org/10.1206/00030090(2006)297[0001:TATOL]2.0.CO;2

Gaitonde, N. \& V. Giri (2014). Primitive breeding in an ancient Indian frog genus Indirana. Current Science 107(1): 109-112.

Gosner, K.L. (1960). A simplified table for staging anuran embryos and larvae with notes on identification. Herpetologica 16(3): 183-190.

Hammer, Ø., D.A.T. Harper \& P.D. Ryan (2001). PAST: Paleontological statistics software package for education and data analysis. Palaeontologia Electronica 4(1): 1-9.

Harris, R.J. (2001). A primer for multivariate statistics. Third Edition. Lawrence Erlbaum Associates Publishers, London.

Huberty, C.J. \& S. Olejnik (2006). Applied MANOVA and Discriminant Analysis. 2nd Edition. Hohn Wiley and Sons, N.J., 488p.

Inger, R.F., H.B. Shaffer, M. Koshy \& R. Bakde (1984). A report on a collection of amphibians and reptiles from the Ponmudi, Kerala, South India. Journal of the Bombay Natural History Society 81: 406427.

IUCN (2008). 'IUCN Policy Statement on Research Involving Species at Risk of Extinction'. Available from: http://intranet.iucn.org/ webfiles/doc/SSC/SSCwebsite/Policy_statements/IUCN_Policy_ Statement_on_Research_Involving_Species_at_Risk_of_Extinction. pdf (accessed 21 February 2014)

IUCN (2014). The IUCN Red List of Threatened Species. Version 2014.2. <www.iucnredlist.org>. Downloaded on 21 August 2014.

Laurent, R.F. (1986). Sous-classe des lissamphibiens (Lissamphibia). Systématique. Traité de zoologie: anatomie, systématique, biologie, tome XIV, fascicle 1B-Batraciens $594-797$.

Milne, I., F. Wright, G. Rowe, D.F. Marshal, D. Husmeier \& G. McGuire (2004). TOPALi: Software for Automatic Identification 
of Recombinant Sequences within DNA Multiple Alignments. Bioinformatics 20(11) : 1806-1807; http://dx.doi.org/10.1093/ bioinformatics/bth155

Modak, N., A.D. Padhye \& N. Dahanukar (2014). Delimiting the distribution range of Indirana leithii (Boulenger, 1888) (Anura: Ranixalidae), an endemic threatened anuran of the Western Ghats, based on molecular and morphological analysis. Zootaxa 3796(1): 62-80; http://dx.doi.org/10.11646/zootaxa.3796.1.3

Myers, C.W. \& W.E. Duellman (1982). A new species of Hyla from Cerro Colorado, and other tree frog records and geographical notes from western Panama. American Museum novitiates 2752: 1-32.

Nair, A., S.V. Gopalan, S. George, K.S. Kumar, A.G.F. Teacher \& J. Merilä (2012a). Endemic Indirana frogs of the Western Ghats biodiversity hotspot. Annales Zoologici Fennici 49: 257-286; http:// dx.doi.org/10.5735/086.049.0501

Nair, A., S.V. Gopalan, S. George, K.S. Kumar, A.G.F. Teacher \& J. Merilä (2012b). High cryptic diversity of endemic Indirana frogs in the Western Ghats biodiversity hotspot. Animal Conservation 2012: 1-10; http://dx.doi.org/10.1111/j.1469-1795.2012.00539.x

Palumbi, S., A. Martin, S. Romano, W.O. McMillan, L. Stice \& G. Grabowski (1991). The simple fool's guide to PCR. Version 2.0 Honolulu Department of Zoology and Marine Laboratory, University of Hawaii, $45 \mathrm{pp}$.

Posada, D. \& K.A. Crandall (2001). Selecting the best-fit model of nucleotide substitution. Systems Biology 50(4): 580-601; http:// dx.doi.org/10.1080/10635150118469

Rao, C.R.N. (1937). On some new forms of Batrachia from S. India. Proceedings of the Indian Academy of Sciences Section B 6: 387427; http://dx.doi.org/10.1007/BF03051434

Savage, J.M. \& W.R. Heyer (1967). Variation and distribution in the tree-frog genus Phyllomedusa in Costa Rica, central America: With 6 figures. Studies on Neotropical Fauna and Environment 5(2): 111131; http://dx.doi.org/10.1080/01650526709360400

Simon, C., F. Friati, A. Beckenbach, B. Crespi, H. Liu \& P. Flook (1994). Evolution, weighting and phylogenetic utility of mitochondrial gene sequences and a compilation of conserved polymerase chain reaction primers. Annals of Entamological Society of America 87: 651-686.

Stamatakis, A. (2006). RAxML-VI-HPC: maximum likelihood-based phylogenetic analyses with thousands of taxa and mixed models. Bioinformatics 22(21): 2688-2690; http://dx.doi.org/10.1093/ bioinformatics/btl446

Stuart, S.N., M. Hoffmann, J.S. Chanson, N.A. Cox, R.J. Berridge, P. Ramani \& B.E. Young (2008). Threatened amphibians of the world. Lynx Edicions, Barcelona, Spain, 758pp.

Tamura, K., G. Stecher, D. Peterson, A. Filipski \& S. Kumar (2013). MEGA6: Molecular Evolutionary Genetics Analysis version 6.0 Molecular Biology and Evolution 30: 2725-2729; http://dx.doi. org/10.1093/molbev/mst197

Vences, M., M. Thomas, A. van der Meijden, Y. Chiari \& D.R. Vieites (2005). Comparative performance of the 16S rRNA gene in DNA barcoding of amphibians. Frontiers in Zoology 2(1): 1-12; http:// dx.doi.org/10.1186/1742-9994-2-5
Author Contribution: ADP diagnosed the species. ADP, NM and ND collected specimens. NM studied the type and comparative material. NM and ND performed molecular analysis. ND performed statistical analysis. ADP, NM and ND wrote the paper.

Author Details: ANAND D. PADHYE is an Associate Professor in Zoology. He works on systematics, ecology, diversity, distribution and evolution of amphibians. NIKHIL MODAK is a doctoral student. He is interested in ecology, systematics and evolution of amphibians of the Western Ghats. NEELESH DAHANUKAR works in ecology and evolution with an emphasis on mathematical and statistical analysis. $\mathrm{He}$ is also interested in taxonomy, distribution patterns and molecular phylogeny of fish and frogs. 
Appendix A. Voucher numbers and GenBank accession numbers for genetic data used for phylogenetic analysis.

\begin{tabular}{|c|c|c|c|c|c|c|c|c|}
\hline \multirow{2}{*}{ Species } & \multicolumn{4}{|c|}{ Voucher } & \multicolumn{4}{|c|}{ GenBank Accession number } \\
\hline & $12 S$ & $16 \mathrm{~S}$ & Rho & Rag1 & $12 S$ & $16 S$ & Rho & Rag1 \\
\hline Indirana chiravasi sp. nov. & \multicolumn{4}{|c|}{ BNHS 5890} & KM386527 & KM386531 & KM386539 & KM386535 \\
\hline Indirana chiravasi sp. nov. & \multicolumn{4}{|c|}{ WILD-14-AMP-489 } & KM386526 & KM386530 & KM386538 & KM386534 \\
\hline Indirana gundia & \multicolumn{4}{|c|}{ WILD-14-AMP-499 } & KM386528 & KM386532 & KM386540 & KM386536 \\
\hline Indirana gundia & \multicolumn{4}{|c|}{ WILD-14-AMP-500 } & KM386529 & KM386533 & KM386541 & KM386537 \\
\hline Indirana leithii & \multicolumn{4}{|c|}{ BNHS 5590} & KF590627 & KF590637 & KF590647 & KM386542 \\
\hline Indirana leithii & \multicolumn{4}{|c|}{ BNHS 5591} & KF590628 & KF590638 & KF590648 & KM386543 \\
\hline Indirana cf. leithii & IND212 & AA212 & DD212 & CC212 & JQ596717 & JQ596673 & JQ596778 & JQ596740 \\
\hline Indirana semipalmata & IND256 & AA256 & DD256 & CC256 & JQ596715 & JQ596671 & JQ596787 & JQ596748 \\
\hline Indirana semipalmata & IND245 & AA245 & DD245 & CC245 & JQ596713 & JQ596669 & JQ596785 & JQ596745 \\
\hline Indirana semipalmata & IND257 & AA257 & DD257 & CC257 & JQ596716 & JQ596672 & JQ596788 & JQ596749 \\
\hline Indirana semipalmata & IND255 & AA255 & DD255 & CC255 & JQ596714 & JQ596670 & JQ596786 & JQ596747 \\
\hline Indirana semipalmata & IND243 & AA243 & DD243 & CC243 & JQ596712 & JQ596668 & JQ596784 & JQ596746 \\
\hline Indirana leptodactyla & IND850 & AA850 & DD850 & CC850 & JQ596719 & JQ596682 & JQ596805 & JQ596761 \\
\hline Indirana leptodactyla & IND848 & AA848 & DD848 & CC848 & JQ596721 & JQ596684 & JQ596803 & JQ596759 \\
\hline Indirana leptodactyla & IND851 & AA851 & DD851 & CC851 & JQ596718 & JQ596685 & JQ596806 & JQ596762 \\
\hline Indirana leptodactyla & IND849 & AA849 & DD849 & CC849 & JQ596720 & JQ596681 & JQ596804 & JQ596760 \\
\hline Indirana leptodactyla & IND847 & AA847 & DD847 & $\mathrm{CC} 847$ & JQ596722 & JQ596683 & JQ596802 & JQ596758 \\
\hline Indirana brachytarsus & IND71 & AA71 & DD71 & CC71 & JQ596690 & JQ596646 & JQ596800 & JQ596751 \\
\hline Indirana brachytarsus & IND638 & AA638 & DD638 & CC638 & JQ596691 & JQ596647 & JQ596799 & JQ596750 \\
\hline Indirana diplosticta & IND92 & AA92 & DD92 & CC92 & JQ596698 & JQ596654 & JQ596813 & JQ596768 \\
\hline Indirana diplosticta & IND94 & AA94 & DD94 & CC94 & JQ596700 & JQ596656 & JQ596815 & JQ596771 \\
\hline Indirana diplosticta & IND91 & AA91 & DD91 & CC91 & JQ596697 & JQ596653 & JQ596812 & JQ596769 \\
\hline Indirana diplosticta & IND93 & AА93 & DD93 & $\mathrm{CC93}$ & JQ596699 & JQ596655 & JQ596814 & JQ596770 \\
\hline Indirana diplosticta & IND98 & AA98 & DD98 & CC98 & JQ596701 & JQ596657 & JQ596816 & JQ596772 \\
\hline Indirana beddomii & IND77 & AA77 & DD77 & $\mathrm{CC} 77$ & JQ596688 & JQ596644 & JQ596795 & JQ596754 \\
\hline Indirana beddomii & IND175 & AA175 & DD175 & CC175 & JQ596692 & JQ596648 & JQ596773 & JQ596730 \\
\hline Indirana beddomii & IND180 & AA180 & DD180 & CC180 & JQ596694 & JQ596650 & JQ596775 & JQ596732 \\
\hline Indirana beddomii & IND193 & AA193 & DD193 & CC193 & JQ596696 & JQ596652 & JQ596777 & JQ596734 \\
\hline Indirana beddomii & IND220 & AA220 & DD220 & CC220 & JQ596708 & JQ596664 & JQ596779 & JQ596736 \\
\hline Indirana beddomii & IND230 & AA230 & DD230 & CC230 & JQ596710 & JQ596666 & JQ596782 & JQ596738 \\
\hline Indirana beddomii & IND244 & AA244 & DD244 & CC244 & JQ596729 & JQ596674 & JQ596789 & JQ596742 \\
\hline Indirana beddomii & IND724 & AA724 & DD724 & CC724 & JQ596726 & JQ596676 & JQ596791 & JQ596743 \\
\hline Indirana beddomii & IND246 & AA246 & DD246 & CC246 & JQ596728 & JQ596675 & JQ596790 & JQ596741 \\
\hline Indirana beddomii & IND800 & AA800 & DD800 & CC800 & JQ596727 & JQ596677 & JQ596792 & JQ596744 \\
\hline Indirana beddomii & IND178 & AA178 & DD178 & CC178 & JQ596693 & JQ596649 & JQ596774 & JQ596731 \\
\hline Indirana beddomii & IND189 & AA189 & DD189 & CC189 & JQ596695 & JQ596651 & JQ596776 & JQ596733 \\
\hline Indirana beddomii & IND200 & AA200 & DD200 & CC200 & JQ596707 & JQ596663 & JQ596780 & JQ596735 \\
\hline Indirana beddomii & IND75 & AA75 & DD75 & $\mathrm{CC75}$ & JQ596687 & JQ596643 & JQ596794 & JQ596753 \\
\hline Indirana beddomii & IND227 & AA227 & DD227 & CC227 & JQ596709 & JQ596665 & JQ596781 & JQ596737 \\
\hline Indirana beddomii & IND231 & AA231 & DD231 & CC231 & JQ596711 & JQ596667 & JQ596783 & JQ596739 \\
\hline Indirana beddomii & IND72 & AA72 & DD72 & $\mathrm{CC} 72$ & JQ596686 & JQ596642 & JQ596793 & JQ596752 \\
\hline Indirana sp. & IND88 & AA88 & DD88 & CC88 & JQ596703 & JQ596659 & JQ596809 & JQ596765 \\
\hline Indirana sp. & IND95 & AA95 & DD95 & CC95 & JQ596705 & JQ596661 & JQ596808 & JQ596764 \\
\hline
\end{tabular}




\begin{tabular}{|c|c|c|c|c|c|c|c|c|}
\hline \multirow{2}{*}{ Species } & \multicolumn{4}{|c|}{ Voucher } & \multicolumn{4}{|c|}{ GenBank Accession number } \\
\hline & $12 S$ & $16 S$ & Rho & Rag1 & $12 S$ & $16 S$ & Rho & Rag1 \\
\hline Indirana sp. & IND99 & AA99 & DD99 & CC99 & JQ596706 & JQ596662 & JQ596811 & JQ596767 \\
\hline Indirana sp. & IND89 & AA89 & DD89 & CC89 & JQ596704 & JQ596660 & JQ596810 & JQ596766 \\
\hline Indirana sp. & IND87 & AA87 & DD87 & CC87 & JQ596702 & JQ596658 & JQ596807 & JQ596763 \\
\hline Micrixalus fuscus & MF5111 & MF3006 & NA & E224.1 & GU143817 & GU136106 & AF249120 & KF991333 \\
\hline
\end{tabular}

NA = not available

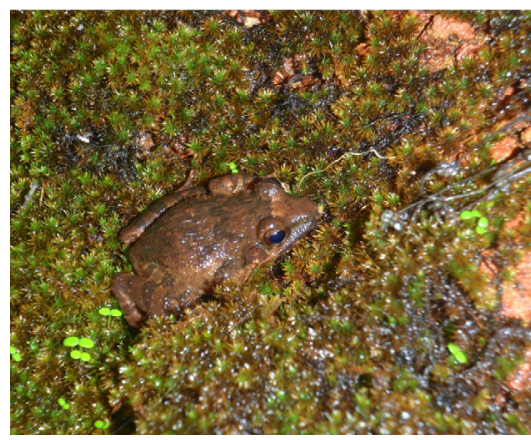

Appendix B. Movie of Indirana chiravasi sp. nov. calling behavior showing single internal vocal sac.

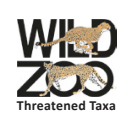

